\title{
T. J. Woofter, Jr., and government social science research during the New Deal, World War II, and the Cold War
}

\author{
Mark Ellis \\ University of Strathclyde
}

This is a peer reviewed accepted author manuscript of the following in-press research article: Ellis, M. (2020). T. J. Woofter, Jr., and government social science research during the New Deal, World War II, and the Cold War. Journal of Policy History, 32(3). 
T. J. Woofter and Government Social Science Research During the New Deal, World War II, and the Cold War.

The writings of Thomas Jackson (Jack) Woofter, Jr. (1893-1972), one of the few southern white Progressives whose main focus was on race relations, are frequently cited by American historians, but the extent of his career and connections in government remain little known. After playing a central role in the interracial cooperation movement in the 1920 s and becoming a pioneering sociologist, he directed federal government research on rural relief in the 1930s, advised on the expansion of social security during and after World War II, and coordinated intelligence and projections on the manpower and productivity of America's adversaries during the Cold War. Through his contributions to the design and delivery of essential programs for key agencies, and collaborations with notable officials, Woofter assisted vital transitions in government policy and social attitudes between 1930 and 1960 .

He also helped to maintain a social science presence in policymaking circles during a period when it was under threat. The in-house, as opposed to philanthropically-funded, academic base of government policymaking began with the Department of Agriculture's engagement with rural sociology after World War I, and expanded during the Great Depression and World War II. After 1945, social science research in government was heavily reduced, but Woofter was among those who continued to provide vital expertise in recently-formed agencies responsible for meeting domestic and global obligations of the United States. Not until the year Jack Woofter retired, in 1958, was an Office of Social Sciences finally created within the National Science Foundation, with an initial budget of $\$ 750,000$, rising to $\$ 10$ million in 1965 , as a new chapter began in the relationship between government and the social sciences. ${ }^{1}$

\footnotetext{
${ }^{1}$ Olaf F. Larson and Julie N. Zimmerman, Sociology in Government: The Galpin-Taylor Years in the U.S. Department of Agriculture, 1919-1953 (University Park: Pennsylvania State University Press, 2003), passim;
} 
Woofter's scholarship on African American education, migration, urban race relations, rural sociology, farm economics, social security, and demography was at the cutting edge of those disciplines and specialisms. His publications are widely acknowledged in numerous studies, but his ability to consolidate and manage research data for official purposes has been largely overlooked. He was a skilled co-ordinator of government research and he was brilliant at synthesizing and presenting complex trends and relationships for specialists, policymakers, legislators, journalists, and general readers. ${ }^{2}$ Throughout, he displayed the instincts of a liberal reformer, supporting expansion of the federal government and searching as he put it, for "the human elements" in the interplay between powerful economic forces and interventionist policy. ${ }^{3}$

This article is structured around three key phases of Woofter's life as a government researcher - the study of rural life during the New Deal, the forecasting of social security and welfare requirements during the 1940s, and the confidential analysis of international demographic data during the Cold War. It assesses his significance and contribution as a social science research director and adviser who communicated widely on major problems and promoted public understanding of government policies during a critical period in modern history. It also illustrates the kind of unpredictable career paths open to academics who were

Martin Bulmer, ed., Social Science Research and Government: Comparative Essays on Britain and the United States (Cambridge: Cambridge University Press, 1987), 2-3. See also Jess Gilbert, Planning Democracy: Agrarian Intellectuals and the Intended New Deal (New Haven: Yale University Press, 2015), 48. Gilbert describes the U.S. Bureau of Agricultural Economics in the 1920 s as "the largest social-science research agency in the federal government and perhaps the largest body of economic experts in the Western world."

2 For examples of work noting Woofter's research, see Dewey W. Grantham, The South in Modern America: A Region At Odds (New York: HarperCollins, 1994), 147; Andrew Wiese, "Blacks in the Suburban and Rural Fringe," in Henry Louis Taylor, Jr., and Walter Hill, eds., Historical Roots of the Urban Crisis: African Americans in the Industrial City, 1900-1950 (New York: Garland, 2000), 158, 166-70; Anthony J. Badger, Prosperity Road: The New Deal, Tobacco, and North Carolina (Chapel Hill: University of North Carolina Press, 1980), 240; W. Fitzhugh Brundage, Under Sentence of Death: Lynching in the South (Chapel Hill: University of North Carolina Press, 1997), 7; Lewis M. Killian, White Southerners (New York: Random House, 1970), 93-94; Mark Lowry II, "Population and Race in Mississippi,1940-1960," Annals of the Association of American Geographers, 61 (Sept. 1971), 576, 588; Charles S. Aiken, The Cotton Plantation South since the Civil War (Baltimore: Johns Hopkins University Press, 1998), 35-39, 52-53. I wish to thank the anonymous JPH reviewers for all their comments. 3 T. J. Woofter, Jr., Landlord and Tenant on the Cotton Plantation (Washington, D.C.: Works Progress Administration, 1936), xvii. 
willing to be deployed as required in public service, and the bureaucratic utility of the adaptable individual with key technical skills and the ability to cross agency boundaries as crises arise.

Born in 1893 and raised in Athens, Georgia, Woofter gained his BA degree from the University of Georgia aged nineteen; after a year of graduate study, he spent fifteen years as a researcher, organizer, publicist, and antilynching activist for the southern interracial cooperation movement, interrupted by two years as a military statistician in the American Expeditionary Force's headquarters and a ground-breaking $\mathrm{PhD}$ at Columbia University on black migration. This immersion in wartime planning and rural demographic projection fostered in Woofter a lasting faith in the power of skilfully presented quantitative data. In 1927, he left the Commission on Interracial Cooperation (CIC) in Atlanta to join Howard W. Odum's Institute for Research in Social Science at the University of North Carolina (UNC) at Chapel Hill. With his salary and research initially funded by the Laura Spelman Rockefeller Memorial, he studied African American demographics and urban conditions, the "evils attending the farm tenant system and conditions in the courts," life on the seas islands, and sub-regional agricultural challenges, such as those faced by tobacco growers. ${ }^{4}$

\footnotetext{
${ }^{4}$ T. J. Woofter, Jr., Negro Migration: Changes in Rural Organization and Population of the Cotton Belt (New York: W. D. Gray, 1920). His PhD was the first correlational study to use multiple regression techniques, according to Stephen P. Turner, "The World of the Academic Quantifiers: The Columbia University Family and its Connections," in Martin Bulmer et al., eds., The Social Survey in Historical Perspective, 1880-1940 (New York: Cambridge University Press, 1991), 283. T. J. Woofter, Jr., and Madge Headley, Negro Housing in Philadelphia (Philadelphia: Institute of Social and Religious Research, 1927). T. J. Woofter, Jr., ed., Negro Problems in Cities (Garden City, NY: Doubleday, Doran, 1928). T. J. Woofter, "The Negro and the Farm Crisis," Social Forces, 6 (June 1928), 615-20. T. J. Woofter, "Race in Politics: An Opportunity for Original Research," Social Forces, 7 (March 1929), 435-38. T. J. Woofter, Jr., Black Yeomanry: Life on St. Helena Island (New York: Henry Holt, 1930). T. J. Woofter, Jr., The Plight of Cigarette Tobacco (Chapel Hill: University of North Carolina Press, 1931). T. J. Woofter, Jr., "Race Relations," American Journal of Sociology, 36 (May 1931), 1039-44. T. J. Woofter and Edith Webb, "A Reclassification of Urban-Rural Population," Social Forces, 11 (March 1933), 34851. T. J. Woofter, "Common Errors in Sampling," Social Forces, 11 (May 1933), 521-25. T. J. Woofter, "Difficulties in Measuring Racial Mental Traits," Social Forces, 13 (March 1935), 415-18. On his career before
} 
At UNC, he produced a report for President Herbert Hoover's commission on African Americans in the US economy and was criticized by W. E. B. Du Bois for placing insufficient weight on racial discrimination. He also contributed a sociological study, "The Status of Racial and Ethnic Groups," to Hoover's Research Committee on Social Trends. In 1933, Odum commended Woofter to Tennessee Valley Authority Director Arthur E. Morgan as "a very genuine spirit as well as a good social statistician," leading to a series of impact studies. ${ }^{5}$ Woofter also improved Odum's regional model for southern studies. Claiming there were "many Souths," he ignored state boundaries, dividing 976 south-eastern counties into twenty-seven seemingly homogenous clusters - the smallest with four counties, the largest with 122 - believing that social and cultural bonds grew from shared geography. Using labels such as "Mining," "Red River," "Blue Grass," "Northern Piedmont," and "SemiTropical," he highlighted local rates of literacy, tenancy, employment, and the ownership of telephones and cars, along with land values and racial composition, and claimed his groupings assisted "practical planning of social programs [and] research into the characteristics of the region." Decades later, they were still used by social scientists. ${ }^{6}$

1930, see Mark Ellis, Race Harmony and Black Progress: Jack Woofter and the Interracial Cooperation Movement (Bloomington: Indiana University Press, 2013).

5 T. J. Woofter, “A Study of the Economic Status of the Negro," June 1930, file 377, series I, frames 253-375, reel 19, Papers of the Commission on Interracial Cooperation, 1919-1944, Woodruff Library, Atlanta University Centre. T. J. Woofter, Jr., "The Status of Racial and Ethnic Groups," in William F. Ogburn, Howard W. Odum, and Edward E. Hunt, eds., Recent Social Trends in the United States, vol. 1 (New York: McGraw-Hill, 1933), 553601; and T. J. Woofter, Jr., Races and Ethnic Groups in American Life (New York: McGraw-Hill, 1933). T. J. Woofter, "The Tennessee Valley Regional Plan," Social Forces, 12 (March 1934), 329-38; T. J. Woofter, "The Tennessee Basin," American Journal of Sociology, 39 (May 1934), 809-17. Woofter correspondence re. "The Tennessee Valley Study, 1933-1934," in Howard W. Odum Papers, Southern Historical Collection (SHC), Wilson Library, University of North Carolina, Chapel Hill (UNC). Morton Sosna, In Search of the Silent South (New York: Columbia University Press, 1977), 61-63. W. E. B. Du Bois, "Woofterism," Crisis, 39 (March 1931), 81-83. Du Bois wanted to "restore to the American Negro his rightful hegemony of scientific investigation and guidance of the Negro problem," and disliked how easily white academics gained support for race studies. Du Bois to Ira DeA. Reid, April 14, 1939, in Herbert Aptheker, ed., The Correspondence of W. E. B. Du Bois, Volume II, Selections, 1934-1944 (Amherst: University of Massachusetts Press, 1976), 187-91.

6 T. J. Woofter, Jr., "The Subregions of the Southeast," Social Forces, 13 (Oct. 1934), 43-50. See also Woofter's critical review of Odum and Moore, American Regionalism (1938) in Rural Sociology, 4 (June 1939), 250-52, and Rupert Bayless Vance, Regionalism and the South: Selected Papers of Rupert Vance, ed. John Shelton Reed and Daniel Joseph Singal (Chapel Hill: University of North Carolina Press, 1982), 189-90. 
During the early 1930s, like other rural sociologists and economists in the South and West, Jack Woofter studied distressed communities and rural relief programs (in 1934, 1.7 million families were dependent on relief). He was critical of the conflicting agendas and methods of the agencies attempting to help farmers in the first two years of the New Deal; nevertheless, in March 1935, he agreed to a temporary transfer to the Federal Emergency Relief Administration (FERA) and eventually chose to remain in what he called "the mad house which is Washington" until he retired. ${ }^{7}$

Woofter worked on sharecropping in the Rural Unit of the FERA's Research Section and in September 1935 became Coordinator of Rural Research. He oversaw the work of rural social workers and state research supervisors in the thirty-one cooperating states and collaborated with sociologists in the long-established Division of Farm Population and Rural Life (DFPRL), part of the Department of Agriculture's Bureau of Agricultural Economics (BAE), led by Carl C. Taylor. According to its historians, DFPRL had been "literally left out of the action during the First Agrarian New Deal," when an array of new schemes was launched in response to the farm crisis. ${ }^{8}$ Woofter saw the South as the main problem, but his FERA remit was national; in 1935, he chaired conferences of FERA officials from eight western states in Salt Lake City and met supervisors from nine western drought states in Omaha. One of his first steps was to improve methods for collecting and sharing data on

\footnotetext{
7 T. J. Woofter, "Southern Population and Social Planning," Social Forces, 14 (Oct. 1935), 16-22; T. J. Woofter, "Rural Relief and the Back-to-the-Farm Movement," Social Forces, 14 (March 1936), 382-88. News-Chronicle [Shippensburg, PA], April 14, 1936, p.4. Woofter approved of the Reconstruction Finance Corporation and the homestead element of the National Industrial Recovery Act. Woofter to Howard Odum, April 5, 1935, folder W-General, box 42, Odum Papers, SHC, UNC.

8 "State Supervisors of Rural Research" folder, box 2, and Progress Reports, March 4-9, March 11-16, 1935, in "Weekly Progress Reports, 1935" folder, box 18, Records of the Division of Social Research, 1933-1942, Records of the Works Progress Administration, Record Group (RG) 69, National Archives II (NA), College Park, MD. Carl C. Taylor, "The Beginnings of Rural Social Studies in the United States Department of Agriculture," Rural Sociology, 4 (June 1939), 219-28. Larson and Zimmerman, Sociology in Government, 195-97, 220-21. See also Richard S. Kirkendall, Social Scientists and Farm Politics in the Age of Roosevelt (Columbia: University of Missouri Press, 1966). On FERA and regional social workers, see Josephine C. Brown, "Rural Families on Relief," Annals of the American Academy of Political and Social Science, 176 (Nov. 1934), 90-94.
} 
relief applicants, employable recipients, rural women, African American youth, "stranded village and small town communities," education, and drought. ${ }^{9}$

In May 1935, the Resettlement Administration was formed, as the New Deal developed longer-term strategies; by December, emergency grants had ended and the FERA was replaced by the Works Progress Administration (WPA), providing work for unemployed adults, and by the Social Security Board, delivering assistance and insurance under the Social Security Act. Woofter transferred to the WPA as its principal agricultural economist and chief of Rural Surveys, supervising studies of rural life and distributing funds to state colleges. He also devised methods for calculating accurately the number of citizens and households receiving relief or emergency employment, showing this peaking at 27.5 million people in 7.8 million households during the winter of 1933-34, and settling at 17 million people in 5.5 million households in $1938 .^{10}$

In all, Woofter oversaw production of fourteen substantial government studies, writing several himself, including Landlord and Tenant on the Cotton Plantation (1936) and a follow-up, The Plantation South, 1934-1937 (1940). Described as "one of the classics on the subject," Landlord and Tenant on the Cotton Plantation was part of an outpouring of academic, official, literary, photographic, cinematic, and journalistic work on American farm tenancy and its place in the wider depression. ${ }^{11}$ Starting in June 1935, Woofter led a team of

\footnotetext{
9 "T. J. Woofter" folder, box 2, and Progress Report, Oct. 7-12, 1935, in "Weekly Progress Reports" folders, box 19, RG 69, NA. Ogden (Utah) Standard-Examiner, Oct. 25, 1935, p.16; Salt Lake Tribune, Oct. 26, 1935, p.18, and Oct. 27, 1935, p.54. On FERA research, see Howard B. Myers, "The General Development and Present Status of the FERA Research Program," Social Forces, 13 (May 1935), 477-81, and Dwight Sanderson, "The Contribution of Research to Rural Relief Problems," ibid., 482-85.

${ }^{10}$ T. J. Woofter, Jr., and T. E. Whiting, "Households and Persons Receiving Relief or Assistance," Journal of the American Statistical Association, 33 (June 1938), 363-72. In 1941, Woofter and Whiting, a WPA statistician, produced the first comprehensive summary on all New Deal agencies and programs. Theodore E. Whiting and T. J. Woofter, Jr., Summary of Relief and Federal Work Program Statistics, 1933-1940 (Washington, D.C.: U.S. Government Printing Office, 1941).

${ }^{11}$ Charles Price Loomis and Joseph Allan Beegle, A Strategy for Rural Change (New York: Schenkman, 1975), 495. For examples of WPA Division of Social Research monographs and other reports, see Waller Wynne, Jr., Five Years of Rural Relief (1938); A. R. Mangus, Changing Aspects of Rural Relief (1938); R. S. Kifer and H. L. Stewart, Farming Hazards and the Drought Area (1938); E. A. Schuler, Social Status and Farm Tenure: Attitudes and Social Conditions of Corn Belt and Cotton Belt Farmers (1938); Carl C. Taylor, Helen W. Wheeler, and E. L.
} 
local enumerators and DFPRL sociologists in detailed surveys of 646 plantations, punchcarding 4,500 tenants' schedules for the 1934 crop year and creating an unprecedented picture of plantation life, finances, land tenure, education, mobility, housing, and health in seven cotton growing south-eastern states. Only half the tenants in the South worked in a cotton plantation setting, but Woofter insisted that persistent "plantation customs and ideology set the pattern for relationships..., and the plantation stands out as the basis for a hereditary oligarchy in southern community life." Chronic poverty, low prices, constant debt, recurrent sickness, incompetent land ownership, and soil erosion were found everywhere, with African American tenants experiencing the worst conditions. ${ }^{12}$ The report, with 170 figures and tables, was not formally transmitted by the WPA until the end of 1936, but in the summer of 1935 the press got wind of it, resulting in reports that "Woofter's private opinion" was that the Agricultural Adjustment Administration (AAA)'s controversial acreage reduction schemes had made conditions worse for tenants and croppers, increasing their eviction rate and boosting the incomes of landlords. ${ }^{13}$ This attack on a flagship program of the first New Deal ensured that Woofter's study attracted wide attention and contributed to a surge in public and congressional sympathy toward impoverished tenants; the press also picked up on Woofter's view that there were no easy, short-term solutions to the tenancy problem and his implied skepticism about the recently-introduced Bankhead-Jones Farm Tenant bill. (The Bankhead-Jones bill, authorizing the federal government to take over and

Kirkpatrick, Disadvantaged Classes in American Agriculture (1938); and Carle C. Zimmerman and Nathan L. Whetten, Rural Families on Relief (1939); Joseph Gaer, Toward Farm Security: The Problem of Rural Poverty and the Work of the Farm Security Administration (1941). For non-government rural poverty studies, see Charles S. Johnson, Shadow of the Plantation (Chicago: University of Chicago Press, 1934); Johnson, Edwin R. Embree, and W. W. Alexander, The Collapse of Cotton Tenancy (Chapel Hill: University of North Carolina Press, 1935); Rupert B. Vance, How the Other Half is Housed: A Pictorial Record of Subminimum Farm Housing in the South (Chapel Hill: University of North Carolina Press, 1936); Arthur Raper and Ira DeA. Reid, Sharecroppers All (Chapel Hill: University of North Carolina Press, 1941); James Agee and Walker Evans, Let Us Now Praise Famous Men (Boston: Houghton Mifflin, 1941).

${ }^{12}$ Woofter, Landlord and Tenant on the Cotton Plantation, xviii, passim. On official sentiment, see Donald $\mathrm{H}$. Grubbs, Cry from the Cotton: The Southern Tenant Farmers' Union and the New Deal (Chapel Hill: University of North Carolina Press, 1971), 136-61.

${ }^{13}$ Express [Lock Haven, PA], Aug. 9, 1935, p.8 
restore damaged land on behalf of tenants, was finally enacted in June 1937, when the Resettlement Administration's projects were absorbed by the Department of Agriculture's new Farm Security Administration). ${ }^{14}$

The director of the WPA, Harry Hopkins, saw Woofter's report as a useful stick with which to beat the AAA and its cautious administrator, Chester C. Davis. This divide between the AAA and the WPA's anti-elitist approach was aired publicly at an ill-tempered convention of fifty rural sociologists and other experts hosted by Howard Odum at Chapel Hill in June 1936. The South, they agreed, was at "a new crossroads of crisis." Addressing the convention, Woofter expressed frustration at disjointed federal farm policies that rewarded landowners and rural businesses and prioritized highways and dams over education. He called for a "national educational plan... and revitalization of the educational system from the kindergarten to the university," and issued a warning: "This accumulation of a great mass of rural population with limited cultural opportunities creates a hotbed of smoldering discontent which at any instant can break out into revolt against the status quo." Another rural sociologist on secondment to Washington, Barnett Osborne Williams of Clemson Agricultural College, accused the government of neglecting "the human factors" in attempting to fix rural America - he had spoken to Secretary of Agriculture Henry A. Wallace about the plight of the farm family "and got no response from him. I argued the importance of the sociological approach, but he thought it would not be scientific. I told him

\footnotetext{
14 Report of Activities, Jan. 2, 1937, Misc. Memoranda, 1935-37 folder, box 3, Central Office Records, RG 69, NA. Pittsburgh Press, Oct. 4, 1936, p.2; New York Times, Dec. 20, 1936, p.8; Washington Post, Dec. 20, 1936, p.M5; St. Louis Post-Dispatch, Dec. 20, 1936, p.21; Shreveport [LA] Times, Dec. 21, 1936, p.6. On the BankheadJones Farm Tenancy Act, see Sidney Baldwin, Poverty and Politics: The Rise and Decline of the Farm Security Administration (Chapel Hill: University of North Carolina Press, 1968), 126-92. Franklin D. Roosevelt, "A Message to Congress on Farm Tenancy. February 16, 1937," in Samuel I. Rosenman, ed., Public Papers and Addresses of Franklin D. Roosevelt: 1937 Volume, The Constitution Prevails (New York: Macmillan, 1941), 8085. Academic reviews of Landlord and Tenant were largely positive (e.g., reviews by Edgar T. Thompson in American Journal of Sociology, 43 (May 1938), 1007-1009, and C. O. Brannen in Rural Sociology, 4 (June 1939), 257-58). Radical scholars demanded a more explicit critique of the AAA and accused government researchers of being "politically timid" (e.g., review by Louise Pearson Mitchell in Journal of Negro History, 22 (July 1937), 350-53).
} 
you could work from the people to the land or from the land to the people. But he could be neither convinced nor interested." These outbursts at Chapel Hill by government officials appeared verbatim in the press. ${ }^{15}$

During 1938-39, Woofter co-wrote The Plantation South, 1934-1937, assessing the impact of the depression and the effectiveness of consequent New Deal measures. During the high-yielding 1937 crop year, he instructed his state supervisors to repeat the 1934 surveys in 246 of the original plantations and found that over the previous three years planters had increased their landholdings, work animals, cultivated acreage, and yields per acre (especially of cotton), all of which ran counter to the AAA's policy of preventing overproduction to sustain farm prices. There were now fewer renters and croppers, and more laborers. Planters' debts were down and their net incomes were up, whereas tenants' average cash income increases (up from $\$ 263$ in 1934 , to $\$ 300$ in 1937) had been wiped out by their new debts. Winter hardship was compounded by substandard diets, housing, and healthcare, while the WPA's work programs offered too few jobs for the underemployed. The President's Committee on Farm Tenancy, chaired by Wallace, had endorsed the BankheadJones proposals for reducing permanent and dependent tenancy, requiring proper leases, and helping resourceful tenants to become landowners, but these gradualist policies were still unimplemented. Clearly, Woofter concluded, "Much remains to be done."16

The implicit radicalism of Landlord and Tenant and The Plantation South was fully embraced by the WPA and in the summer of 1938, at Hopkins's suggestion, Woofter popularised their message by writing Seven Lean Years (1939) with Ellen Black Winston, a North Carolinian junior member of the WPA's Division of Research. Unlike Woofter's

\footnotetext{
${ }_{15}$ New York Times, June 19, 21, 22, 1936, p.13. Christian Science Monitor, June 24, 1936, p.2. Pittsburgh Courier, June 27, 1936, p.2.

16 William C. Holley, Ellen Winston, and T. J. Woofter, Jr., The Plantation South, 1934-1937 (Washington, D.C.: U.S. Government Printing Office, 1940), iii, xi, xv-xxii.
} 
official publications, which were put out by the U.S. Government Printing Office, Seven Lean Years was published by the University of North Carolina Press and aimed at a white general audience. Hopkins saw it as useful propaganda for rural relief and an opportunity to contrast the Roosevelt and Hoover administrations. The book was an ominous "national analysis" of farm life from 1931 to 1937, during which the FERA, the Resettlement Administration and the WPA had spent $\$ 3.5$ billion in attempting to relieve distress in rural communities, and the USDA spent a further $\$ 10$ billion on price-fixing and direct grants. ${ }^{17}$

By synthesizing the findings of the FERA and WPA research divisions, Woofter and Winston intended to offer "a nontechnical summary of the fundamental aspects of maladjustment in rural areas and outline methods for the reconstruction of rural life which should prevent the recurrence of needless distress." Instead of an agronomical survey, they declared, Seven Lean Years would take a "humanitarian" look at extreme rural poverty without "sentimentalism and political claptrap," but it was nevertheless the most polemical thing Woofter ever wrote. The authors set out their "abiding conviction that it is important to the national welfare that positive programs of agrarian and social reform be vigorously pursued." They called for permanently raised living standards through "very fundamental planning" and programs that would have benefited farming long before the depression. ${ }^{18}$ They chose sixteen WPA photographs to contrast the bleakness of "Displaced Tenants," "A

\footnotetext{
17 Winston paid tribute in his obituary to Woofter's mentoring of junior staff. Ellen Winston, "Thomas Jackson Woofter, 1893-1972," Footnotes, 1 (Jan. 1973), 6. Her PhD on poverty in southern sub-regions was supervised by University of Chicago demographic sociologist William F. Ogburn. In 1944, she became North Carolina commissioner of public welfare and, in 1963, the first U.S. commissioner of welfare in the Department of Health, Education, and Welfare. Eileen Boris, "Ellen Black Winston: Social Science for Social Welfare," in Michele Gillespie and Sally G. McMillen, eds., North Carolina Women: Their Lives and Times, Volume 2 (Athens: University of Georgia Press, 2015), 238-61. In 2002, disclosures about sterilization under the Eugenics Board of North Carolina, which Winston chaired, led to a gubernatorial apology. See Johanna Schoen, Coercion and Choice: Birth Control, Sterilization, and Abortion in Public Health and Welfare (Chapel Hill: University of North Carolina Press, 2005), 75-139, 241-50. John Railey, Kevin Begos, and Danielle Deaver, "Little Notice and Less Explanation," Winston-Salem Journal, Feb. 16, 2003, at http://extras.journalnow.com/againsttheirwill/parts/epilogue/storybody8.html 18 T. J. Woofter, Jr., and Ellen Winston, Seven Lean Years (Chapel Hill: University of North Carolina Press, 1939), v, vi-vii, 2
} 
Large Relief Family on Poor Land," tented migrant camps, soil erosion, and dust storms, with optimistic images of rural schools and clinics, smiling young laborers on federal projects, a "Rehabilitated" farmer with hog carcasses in his well-stocked storeroom, and "The Millionth WPA Pupil” studying farming methods.

All the photographs and almost all the family case histories included were of white people, despite the desperate situation of millions of rural African Americans. Revealingly, the book's longest reference to black farmers was taken from a study Woofter had published a decade earlier about a South Carolina sea island. ${ }^{19}$ In 1935, southern black sharecroppers on direct relief received the lowest monthly payments of all groups under the FERA principle of "budgetary deficiency" - just $\$ 4$ per household - while the one-in-five white farm owners relying on work relief in the Great Lakes cut-over area received \$27 a month. Woofter and Winston skated over this with the comment that in 1933 payments had been even lower and stated, "The adequacy of relief grants was in large measure determined by the administrative policies in the various states and by the amount of funds available." 20 They were both liberal white southerners, but they complied with the racist orthodoxy as to whose misery mattered most. Historian Eileen Boris attributes this relentless stress on the white family, not so much to the authors' bias, as to "a reform strategy to give poverty a white face" in view of the Democratic Party's dominance in the South and its disproportionate power in congressional committees and presidential elections. ${ }^{21}$

\footnotetext{
19 Ibid., 84-85. Woofter, Black Yeomanry, 119-20.

${ }^{20}$ Woofter and Winston, Seven Lean Years, 154-55. Average monthly payment to sharecropper families in June 1935 was \$9. Charles P. Loomis et al., Standards of Living in the Great Lakes Cut-Over Area (Washington, D.C.: U.S. Department of Agriculture, 1938).

${ }^{21}$ Boris, "Ellen Black Winston," 245. On key questions about race and liberalism in the 1930s, see William B. Thomas, "Conservative Currents in Howard Washington Odum's Agenda for Social Reform in Southern Race Relations, 1930-1936," Phylon, 45 (2nd Qtr., 1984), 121-34. Woofter knew the urban liberals of the AAA and the younger New Dealers who strove for racial justice and tenants' rights, such as Clark Foreman and Virginia Foster Durr, but he did not associate with either group.
} 
Woofter and Winston saw the "drama of the depression" as a chance to give lasting assistance to poor people who were hammered by low farm prices, drought, and public assistance cutbacks in 1937 but would gain nothing from the Social Security Act or New Deal hours and wages regulations. The sorry story of rural insecurity was all too familiar: once-successful families were now marooned by single crop production and irreparable erosion, low incomes, minimal savings, precarious tenancy, mounting taxes, debts, and foreclosures. Communities of small farms and towns were finally "submerged" when markets shrank, credit evaporated, machines began to displace labor, and cash incomes from rural construction, mining, or logging vanished (just one-in-eight farm laborers found employment in 1935 that did not derive from a government program). ${ }^{22}$

Tenants, especially young sharecroppers raising cotton or tobacco, were so trapped by debt and short leases that even a good yield might make little difference. Americans might not like the term, "peasant," Woofter and Winston observed, but it aptly described many citizens. They calculated that the incomes of five million farm families were below minimum urban subsistence levels and three million lived in complete poverty. Farm owners were not immune: the margins between success and failure were so narrow that half the 500,000 farm families on the FERA's emergency relief rolls in 1935 were owners facing heavy debts, drought, or ill-health. Rural youth transience, inadequate schooling and training, poor health, diets, and sanitation led Woofter and Winston to warn that "the depression will leave a lasting imprint on the next generation," unless the wealthy contributed more. ${ }^{23}$ The most "chronically underprivileged" families were found where the boll weevil struck cotton growers after 1910 and in the "Appalachian-Ozark, Lake States Cut-Over, Spring Wheat, and Winter Wheat" regions. Texas and Oklahoma also suffered high transport

\footnotetext{
22 Woofter and Winston, Seven Lean Years, 5-44.

23 Ibid., 45-87.
} 
costs and droughts in 1934 and 1936, and southern mountain regions from West Virginia to Arkansas battled eroded hillsides, deforestation, poor roads, and low literacy. Woofter and Winston concluded that, despite the recent efforts of the FERA Rehabilitation Program, the Resettlement Administration, the Soil Conservation Service, the Red Cross, and the Reconstruction Finance Corporation, millions of farm families faced a permanent dependence on relief. ${ }^{24}$

They therefore appealed for long-term policies to prevent distress They proposed large-scale flexible rehabilitation loans, supported by FSA land-use and home economics experts, and permanent public works programs to resettle all "relief farmers [in a] ... regionally balanced agriculture.” Acreage control, they argued, could cut commercial production as part of long-range planning, but not as a quick fix. Surplus food should be distributed cheaply or free, as in Sweden, "especially when the poorer classes are rearing the future population," while cooperatives would prevent deflationary surpluses and spread income equitably. They also called for a "population policy" to encourage "heavy migration" away from farms in drought-hit and cotton regions and envisaged an ideal mixture of farming, decentralized industry, and housebuilding to create employment. Finally, an attractive credit system, appropriate education, and new public health services would transform rural life..$^{25}$

They called on Congress to pay for this vision by using "the broader tax base of the whole nation." States with the biggest rural problems could never afford the required investment; their low tax returns meant they struggled just to match federal spending on unemployables, the aged, and children under the Social Security program. Woofter and Winston declared: "It is self-evident that if national standards of security and public welfare

\footnotetext{
24 Ibid., 89-147.

25 Ibid., 148-73. On farm cooperatives, see Ellis Cowling, Co-operatives in America: Their Past, Present and Future (New York: Coward-McCann, 1938).
} 
are to continue to advance, increasing participation of the national government in equalizing state finances is necessary." Only then, would a massive enlargement of essential services create jobs and give rural America the same standards as the cities:

If a reasonable amount of foresight is exercised, American agriculture can be prevented from declining to the point where American farmers are forced to a peasant standard of living. However, if with the return of normal prosperity the rural sore spots are forgotten, they may be counted upon to pile up a staggering relief bill again whenever the national economy is thrown out seriously out of balance. ${ }^{26}$

The first New Deal had tried to maintain industrial workers' incomes and the demand for agricultural output, in the hope that farm families' purchasing power would alleviate the depression. The policy had failed, and relieving rural distress now offered limited gains: "A long-range plan of attack not subject to emergency psychology should be the goal.” Basically, the farmer's problems predated the slump - and the government needed to rehabilitate the victims of "the pioneering and the exploitative" stages of American agriculture. Woofter and Winston rounded off with a unifying New Deal flourish: "[T]he future welfare of America is at stake, and inextricably bound up with the welfare of rural areas. ... The nation cannot be permanently prosperous unless it rests on the solid foundation of a prospering rural population." 27

Perhaps Seven Lean Years is best understood as an expression of what socio-historian Jess Gilbert has referred to as the "Intended New Deal." Certainly, in 1938, a new momentum was needed if radical interagency collaboration was to help the rural

\footnotetext{
${ }^{26}$ Woofter and Winston, Seven Lean Years, 174-76.

27 Ibid., 149, 151, 176. See also Carle C. Zimmerman, review of Seven Lean Years, in American Journal of Sociology, 45 (Nov. 1939), 496-97. Popular treatments of federal rural research included Howard R. Tolley, The Farmer Citizen at War (New York: Macmillan, 1943), on New Deal planners' preparations for the coming war, and Arthur Raper, Tenants of the Almighty (New York: Macmillan, 1944), partly devoted to the DFPRL's landuse planning programs, as they operated in Greene County, Ga.
} 
disadvantaged. The United Farm Program and the Rural Life Trends Project sparked some interest in Congress in the work of the BAE and the Farm Security Administration (FSA), while Woofter and Winston were attempting what Gilbert calls an agrarian dialogue "between expert and citizen," but by now the energy of the New Deal was drained. ${ }^{28}$

In July 1939, amid a broad government reorganization, Woofter moved to the FSA, becoming chief economist and adviser to its administrator, Will Alexander, formerly head of the Resettlement Administration. During the 1920s, Woofter was one of Alexander's closest colleagues in the Commission on Interracial Cooperation in Atlanta and his FSA appointment was typical of Alexander's personal approach to filling senior positions. (A year later, in July 1940, Alexander departed for the National Defense Commission and the Rosenwald Fund, and was succeeded by C. B. Baldwin, an equally liberal Wallace associate.) ${ }^{29}$ Woofter appeared with Alexander before the civil liberties subcommittee of the Senate Committee on Education and Labor, arguing for proper rehabilitation for farm families to limit wasteful migration, and seeking new tenancy reforms and access to public works for all rural Americans. ${ }^{30}$ He began work on a celebration of a decade of rural rehabilitation, but the FSA - described by historian Otis L. Graham, Jr., as "an odd combination of the anachronistic and the visionary" - was already faltering. Under Alexander and Baldwin, it remained an enclave of New Deal humanitarianism toward small farmers, including African Americans, but its resources lagged behind its practical democratic ambitions and its ability to aid tenants was

\footnotetext{
28 Gilbert, Planning Democracy, 47, Part II. Congressional opinion was wary of land-use interventions, especially when farm policy and race intersected. Larson and Zimmerman, Sociology in Government, 51-55, 224-44. See also, Leo J. Zuber, review of Seven Lean Years, in Tennessee Planner, 1 (Jan.-Feb. 1940), 19-22. 29 Personnel File, Thomas Jackson Woofter, Jr. (d.o.b. 6/18/93), Civilian Personnel Records, National Personnel Records Center (NPRC), St. Louis, Mo. Wilma Dykeman and James Stokely, Seeds of Southern Change: The Life of Will Alexander (New York: Norton, 1962), 224-50.

${ }^{30}$ New York Times, May 24, 1940, p.21. Senate Committee on Education and Labor, $76^{\text {th }}$ Congress, Violations of Free Speech and Rights of Labor, May 23, 1940, p.669-709. Congressional criticism contributed to the resignations of both Alexander and Baldwin. The FSA was replaced by the Farmers Home Administration in 1946. Baldwin, Poverty and Politics, 325-402. On FSA, see also Charles Kenneth Roberts, The Farm Security Administration and Rural Rehabilitation in the South (Knoxville: University of Tennessee Press, 2015); Larson and Zimmerman, Sociology in Government, 202-19; Kirkendall, Social Scientists and Farm Politics, 129-32.
} 
limited. Undaunted, and despite inherent financial and jurisdictional obstacles, and growing antagonism toward the FSA in Congress, Woofter called again for a policy of reducing the surplus farm population and taking sub-marginal farmland out of cultivation to combat malnutrition and disease. ${ }^{31}$ These things were delivered, to a degree, less by the New Deal, than by American entry into World War II.

In December 1940, Woofter resigned from the FSA to become research director of the new U.S. Federal Security Agency (USFSA). This agency, which became the Department of Health, Education, and Welfare in 1953, played a crucial role in policy transitions from New Deal to wartime, and from war to peacetime. It worked closely with the states and was the core vehicle for planning and delivering social security and public services during the 1940s. As one of its most senior appointees, Woofter advised the USFSA administrator, former Indiana governor Paul V. McNutt. He also directed a swathe of social science research across sixteen bureaus, including the Social Security Board, Office of Education, the Civilian Conservation Corps, National Youth Administration, the Children's Bureau, Food and Drug Administration, and the U.S. Public Health Service. His own research generated advanced methods for projecting demographic shifts and social security budget requirements. ${ }^{32}$

\footnotetext{
31 T. J. Woofter, Jr., and A. E. Fisher, The Plantation South Today (Washington, D.C.: U.S. Government Printing Office, 1940). Bradford [PA] Evening Star, June 25, 1940, p.6; New York Age, Nov. 9, 1940. p.11. Larson and Zimmerman, Sociology in Government, 203-204, 221. Roger Biles, A New Deal for the American People (DeKalb: Northern Illinois University Press, 1991), 67-68, 75. Otis L. Graham, Jr., Toward a Planned Society: From Roosevelt to Nixon (New York: Oxford University Press, 1976), 44-45. Woofter advised southern reform spokesman UNC President Frank Porter Graham before his testimony to the Senate's Special Committee to Investigate Unemployment and Relief in March 1938 and advised the Swedish sociologist, Gunnar Myrdal on southern race relations for An American Dilemma (1944). James F. Byrnes to Graham, Feb. 23, 1938; Ray E. Wakeley to Graham, March 2, 1938, folder 705, Frank Porter Graham Papers, Subseries 1.1, 1938, SHC, UNC. Progress reports, April 29, June 17, July 1, July 15, 1939, in "Weekly Progress Reports" folder, box 19, RG 69, NA. Gunnar Myrdal, An American Dilemma: The Negro Problem an American Democracy (New York: Harper, 1944), 1337.

32 Woofter personnel file, NPRC. "Dr Woofter Research Director Federal Security Agency," Population Index, 7 (Jan. 1941), 13. "USFSA" is used here to avoid confusion with the Farm Security Administration (FSA). The bureau heads were all political appointees.
} 
In a critical evaluation of the USFSA, Mariano-Florentino Cuellar notes that its wartime remit also included "civil defense preparedness, supplying employees to war-related industries, facilitating the relocation of Japanese-Americans, antiprostitution enforcement, and biological weapons research." This controversial centralization of executive power included domestic regulatory and national defense functions that would continue after the war, leading USFSA officials to assert "the contribution made by research and statistics to national security."33 In 1941-42, after McNutt assumed chairmanship of the War Manpower Commission, Woofter provided data and analysis for the Selective Service System. ${ }^{34} \mathrm{He}$ also addressed the National Conference of Social Work on pressures caused by sudden migration of workers to towns with defense plants and he appeared repeatedly before congressional committees to explain the chaos caused in several states by people with no supporting documents rushing for birth certificates after the 1941 War Act barred companies with government contracts from hiring aliens. ${ }^{35}$

In 1942-43, the government launched a series of planning activities for the post-war period, led by the Board of Economic Warfare, the National Resources Planning Board (NRPB), and the Federal Reserve. Woofter headed the USFSA's response through a program planning committee tasked with expanding social security, education, and health services. Promising to work through state and local agencies, he called for "getting planning down as

\footnotetext{
33 Mariano-Florentino Cuellar, "'Securing" the Nation: Law, Politics, and Organization at the Federal Security Agency, 1939-1953," University of Chicago Law Review, 76 (Spring 2009), 587-718. Louis Levine to Jack Woofter, Nov. 9, 1948, file 025, box 55, RG 235, Records of the Federal Security Agency, in Records of the Department of Health, Education, and Welfare, NA. In 1938, FDR proposed a Department of Public Welfare, but Congress objected; hence, the creation of the Federal Security Agency under the Reorganization Act of 1939. Richard Polenberg, Reorganizing Roosevelt's Government: The Controversy over Executive Reorganization, 1936-1939 (Cambridge, MA: Harvard University Press, 1966), 146-62. Biological weapons research was undertaken by the USFSA's secret bureau, War Research Services.

34 Lewis Hershey to T. J. Woofter, March 6, 1946, file 200.1, box 166, RG 235, NA.

${ }^{35}$ T. J. Woofter, Jr., Community Problems in Defense Areas (Chicago: American Public Welfare Association, 1941). House Committee on Census, $77^{\text {th }}$ Congress, Authorizing the Director of the Census to Issue Birth Certificates, June 10, 1942, p.65-73. House Committee on Immigration and Naturalization, $77^{\text {th }}$ Congress, Documentary Evidence of Citizenship, Feb. 11, 12, 17, 1942, p.27-30. Senate Committee on Commerce, $78^{\text {th }}$ Congress, Establishing a Bureau of Vital Records in the U.S. Public Health Service, Jan. 13, 1944, p.24-26.
} 
close to Main Street as you can get it." He also represented the agency on the NRPB's special Committee on Long-Range Work and Relief Policies, with New Deal veterans Will Alexander, Katharine F. Lenroot of the Children's Bureau, and Corrington C. Gill of the Office of Civil Defense. Their 550-page "social revolution" report, "Security, Work, and Relief Polices," was sent to the White House in December 1941 (a year before publication of Sir William Beveridge's plan for post-war Britain, Social Insurance and Allied Services), but Roosevelt delayed providing it to Congress until March 1943, when its Beveridge-ish "cradle to the grave" welfare proposals were promptly attacked as "socialistic." (The 1943 and 1945 Wagner-Murray-Dingell bills, inspired by this NRPB report, were blocked by the American Medical Association.) The report was followed in July 1943 by the NRPB's demobilization proposals, prepared by the Conference on Post-War Readjustment of Civilian and Military Personnel, on which Woofter again represented the USFSA. The demobilization report, one of the last things the board produced before it was abolished by Congress, was attacked by the Republican Party as "a bold bid for the vote of our soldiers and sailors." Nevertheless, NRPB analyses contributed to the design and passage of the Servicemen's Readjustment Act (G.I. Bill) in 1944. ${ }^{36}$

\footnotetext{
${ }^{36}$ Security, Work, and Relief Policies (Washington, D.C.: U.S. Government Printing Office, 1942). Berkshire Eagle [Pittsfield, MA], Oct. 8, 1942, p.5; Chicago Tribune, Dec. 11, 1942, p.2; New York Times, March 11, 1943, p.1, 13; Pittsburgh Press, March 11, 1943, p.9; Oakland Tribune, March 11, 1943, p.16; New York Times, July 31, 1943, p.1. Cincinnati Enquirer, March 14, 1943, p.5. Arthur J. Altmeyer, The Formative Years of Social Security (Madison: University of Wisconsin Press, 1966), 143-51. W. H. Beveridge, Social Insurance and Allied Services (London: HMSO, 1942). See also Martha Derthick, Policymaking for Social Security (Washington, D.C.: Brookings Institution, 1979). On NRPB, see Charles E. Merriam, "The National Resources Planning Board: A Chapter in American Planning Experience," American Political Science Review, 38 (Dec. 1944), 1075-88. On the contrasts in social sciences growth in the USA and Britain, and the differing relationships between academe and public policy, see Martin Bulmer, "National Contexts for the Development of Social-Policy Research: British and American Research on Poverty and Social Welfare Compared," in Peter Wagner et al., eds., Social Sciences and Modern States: National Experiences and Theoretical Crossroads (Cambridge: Cambridge University Press, 1991), 148-67; Björn Wittrock and Peter Wagner, "Social Science and the Building of the Early Welfare State: Toward a Comparison of Statist and Non-Statist Western Societies," in Dietrich Rueschemeyer and Theda Skocpol, eds., States, Social Knowledge, and the Origins of Modern Social Policies (Princeton: Princeton University Press, 1996), 90-113; Libby Schweber, "Progressive Reformers, Unemployment, and the Transformation of Social Inquiry in Britain and the United States, 1880s-1920s," ibid., 163-200.
} 
One of Woofter's main wartime contributions was nailing down the post-war costs of amendments made in 1939 to the original Social Security Act (although he did not suggest how those costs might be met or contained). As Wilbur J. Cohen, one of those responsible for the changes, put it, they "transformed it from just an old-age insurance program to an oldage and survivors' insurance program." ${ }^{37}$ In response to new provisions covering workers' widows and dependants, the Social Security Board tried to predict future survivors' benefits and maintenance budgets, while allowing for racial and regional income disparities, variable family composition, and post-war disability rates. ${ }^{38}$ Woofter used North Carolina as a testbed for the effects of this expansion of post-war social security provision. He also consulted with the leading African American sociologist, E. Franklin Frazier of Howard University, on black family income levels and exchanged detailed correspondence with prominent American demographers and actuaries Frank Lorimer, P. K. Whelpton, Louis I. Dublin, and Alfred J. Lotka, concerning methods for estimating the number of paternal orphans over five-yearly intervals - "a problem of very practical significance.” As summarized in Hugh Wolfenden's Population Statistics and Their Compilation, Woofter's calculations "were made by taking the number of births by age of father in each of the preceding 18 years, applying the death rates of fathers by age to determine the number of deaths among fathers, and using survival rates of children to compute the number of orphans surviving to the specified year." 39

\footnotetext{
${ }^{37}$ Katie Loucheim, ed., The Making of the New Deal: The Insiders Speak (Cambridge, MA: Harvard University Press, 1983), 157-58. Although federal social security was widened, more was paid out by the states' worker compensation schemes and veterans' programs. Edward Berkowitz, "Social Welfare and the American State," in Donald T. Critchlow and Ellis W. Hawley, eds., Federal Social Policy: The Historical Dimension (University Park: Pennsylvania State University Press, 1988), 172-73.

${ }^{38}$ T. J. Woofter, Jr., "Preliminary Population Estimates Based on Ration Book Applications," Journal of the American Statistical Association, 37 (Dec. 1942), 437-40; T. J. Woofter, Jr., "A Method of Analysis of Family Composition and Income," Journal of the American Statistical Association, 39 (Dec. 1944), 488-96; T. J. Woofter, "Size of Family in Relation to Family Income and Age of Family Head," American Sociological Review, 9 (Dec. 1944), 678-84; T. J. Woofter, "Southern Children and Family Security," Social Forces, 23 (March 1945), 366-75, and reprinted in Howard W. Odum and Katharine Jocher, eds., In Search of the Regional Balance of America (Chapel Hill: University of North Carolina, 1945), 124-33.

${ }^{39}$ Hugh H. Wolfenden, Population Statistics and Their Compilation (Chicago: University of Chicago Press, 1954), 225. Woofter to Gordon Blackwell, Sept. 25, 1945, file 052, box 130, RG 235, NA. Woofter to Martin Marimont, Jan. 6, 1945, ibid; Woofter to A. J. Lotka, June 14, 1945, ibid (this letter was 3,000 words long).
} 
Woofter, who began work on population statistics at UNC, saw this as the best way round the problem of predicting future patterns when the only firm yardstick was the decennial census. $^{40}$

Throughout the New Deal he had commented on demographic issues with increasing urgency and authority, and was referred to in the press as "the WPA's population expert." 41 Hopkins approved Woofter's participation in the 1937 International Congress on Population Problems in Paris, where his presentation emphasized "the human elements that press for attention on the part of those guiding the nation's destiny." He complained that the USA lacked a "clear-cut policy [for] population planning" and urged "further research, exact and detailed knowledge" concerning annual increases in young job seekers, low urban birth rates, migration back to the poorest land, and the projected increase in old people from 6.6 million in 1930 to 14.2 million by $1960 .{ }^{42}$ He told a joint meeting of the Population Association of America (PAA) and the American Sociological Society in 1939 that, although employment

\footnotetext{
Woofter to Franklin Frazier, April 5, 1946, ibid. Howard University was administered by the USFSA. Recent research notes the obstacles to gaining certain kinds of work in the South for African Americans in the 1940s, but suggests racial wage differentials, themselves, were not large. See Celeste K. Carruthers and Marianne H. Wanamaker, "Separate and Unequal in the Labor Market: Human Capital and the Jim Crow Wage Gap," Working Paper 21947 (National Bureau of Economic Research, Jan. 2016), 51pp. T. J. Woofter, "Children and Family Income," Social Security Bulletin, 8 (Jan. 1945), 1-6; T. J. Woofter, "Children and Family Security," Social Security Bulletin, 8 (March 1945), 5-10; T. J. Woofter, "Probabilities of Death in Closed Population Groups, Illustrated by Probabilities of Death of White Fathers after Birth of Children," Human Biology, 18 (Sept. 1946), 158-70. See also, Frank W. Notestein, "Demography in the United States: A Partial Account of the Development of the Field," Population and Development Review, 8 (Dec. 1982), 651-87. Dublin and Lotka worked for Metropolitan Life insurance company.

${ }^{40} \mathrm{~T}$. J. Woofter, Jr., "Interpolation for Populations Whose Rate of Increase is Declining," Journal of the American Statistical Association, 27 (June 1932), 180-82.

${ }^{41}$ Dunkirk [NY] Evening Observer, May 16, 1939, p.13. See, for example, T. J. Woofter, Jr., "What is the Negro Rate of Increase?" Journal of the American Statistical Association, 26 (Dec. 1931), 461-62. T. J. Woofter, Jr., "Southern Population and Social Planning," Social Forces, 14 (Oct. 1935), 609-18. T. J. Woofter, Jr., "The Natural Increase of the Rural Non-Farm Population," Milbank Quarterly, 13 (Dec. 1935), 311-19. T. J. Woofter, Jr., "Replacement Rates in the Productive Ages," Milbank Quarterly, 15 (Dec. 1937), 438-54. T. J. Woofter, Jr., "The Future Working Population," Rural Sociology, 4 (Sept. 1939), 275-82.

${ }^{42}$ Gazette and Daily [York, PA], Aug. 9, 1937, p.3. Intermittent conferences followed the 1927 World Population Conference in Geneva, chaired by Margaret Sanger under League of Nations auspices (the culmination of six international birth control conferences). At the Paris Conference, where population collapse due to falling fertility was predicted, proposed German and Italian participation led to boycotts. Schoen, Coercion and Choice, 198. New York Times, July 30, 1937, p.4. Woofter to Hopkins, June 25, 1937, folder 27, box 54, Harry L. Hopkins Papers, Special Collections Division, Georgetown University, Washington, D.C.
} 
had reached 1930 levels (i.e., 35 million), unemployment had doubled to 11 million because a million young people reached working age annually. This required the USA to create 19.5 million jobs over the next two decades. He saw little point in trying to limit population growth through birth control and immigration restriction, because falling birth rates would produce an eventual rise in the average age of the population. Instead, in statements that echoed his work on agriculture, he pointed to demographic projections showing the need for a "long-range public employment program [and a] different distribution of income - an increase in the purchasing power of the lower third of the population." 43 He repeated these radical warnings in 1940, when he became PAA president and joined other leading demographers, such as Whelpton, Lorimer, William F. Ogburn, and Rupert B. Vance, in advising individual state planning boards and giving radio talks for the PAA. Although Woofter collaborated with mid-century American social demographers who advanced theories concerning the cause and effects of population change, he did not share the enthusiasm of some of them for social eugenics, and as PAA president he helped distance the association from its eugenicist, birth control, and nativist origins. ${ }^{44}$

In the aftermath of depression and war, no government could enhance the welfare system and maintain national security without effective statistical forecasting concerning manpower and fertility. In 1944, Woofter and the Census Bureau noted continuing concerns that American birth rates, especially in cities, might not replace the existing population and

\footnotetext{
${ }^{43}$ Dunkirk Evening Observer, May 16, 1939, p.13; Harrisburg [PA] Evening News, Dec. 27, 1939, p.1; Gazette and Daily), Dec. 29, 1937, p.6. Woofter advised the Children's Bureau's White House Conference on Children in a Democracy in January 1940. See Proceedings... [Bureau Publication No. 266] (Washington, D.C.: U.S. Government Printing Office, 1940).

44 Binghamton Press and Sun-Bulletin, March 13, 1940, p.25. Newport News Daily Press, April 16, 1940, p.12. Edmund Ramsden, "Social Demography and Eugenics in the Interwar United States," Population and Development Review, 29 (Dec. 2003), 547-93. “Association Cooperates in Radio Series," Population Index, 6 (Oct. 1940), 255-56. Woofter also sat on the Rural Sociological Society executive with Carl C. Taylor of USDA and Dwight Sanderson of Cornell University, and joined Taylor as an incorporator of the American Sociological Society (later, Association) in 1943. Lawrence J. Rhoades, A History of the American Sociological Association, 1905-1980 (1981) at http://www.asanet.org
} 
labor force, even if the already-evident baby boom persisted. This was part of an old debate about the optimum size of the American population, in which long-term stability was increasingly seen as the best outcome. ${ }^{45}$ During and after World War II, Woofter refined American reproductivity measurements, by focusing less on the number of births for any given year, and more on the fertility and mortality of a given cohort of women. By comparing reproductivity of women aged 15 to 44 in 1944 with female mortality rates since 1915, he arrived at a "generation net reproductive rate." This differed from conventional methods and showed the reproduction rates between 1923 and 1938 of American women born between 1895 and 1910 falling less fast than other studies; Woofter's approach would be taken forward by Whelpton. ${ }^{46}$

At the end of the 1940s, Woofter commented on the number of demographers, including himself, who had wrongly predicted that fertility and populations would continue to decline in industrial societies. He now attributed falling birth rates in the 1930 s and rising rates in the 1940s to economic fluctuations: during and after the war higher incomes made having children more affordable and the effect of better living standards was to slash rates of sterility, infant mortality, and prenatal death; for example, the death rates of five-year-old

\footnotetext{
${ }^{45}$ Medford [OR] Mail Tribune, June 22, 1944, p.8. Derek S. Hoff, The State and the Stork: The Population Debate and Policy Making in US History (Chicago: University of Chicago Press, 2012), 11-12. On the baby boom, see Dan Bouk, "Generation Crisis: How Population Research Defined the Baby Boomers," Modern American History, 1 (Nov. 2018), 321-42. Frederick E. Hosen, The Great Depression and the New Deal (Jefferson, NC: McFarland, 1992), 250-55.

${ }^{46}$ Henry S. Shyrock, Jacob S. Siegel, et al., The Methods and Materials of Demography, Volume 2 (Washington, D.C.: U.S. Government Printing Office, 1973), 537-39. T. J. Woofter, "Completed Generation Reproduction Rates," Human Biology, 19 (Sept. 1947), 133-53; T. J. Woofter, "The Relation of the Net Reproduction Rate to Other Fertility Measures," Journal of the American Statistical Association, 44 (Dec. 1949), 501-517. Jean van der Tak, Arthur Campbell interview, Feb. 16, 1988, Demographic Destinies, 1/2 (2005), 285. See also, P. K. Whelpton, "Cohort Analysis of Fertility," American Sociological Review, 14 (Dec. 1949), 735-49. Woofter's cohort studies led to disagreements with Lotka, one of the founders of mathematical demography. Louis Henry, "L'assemblée de l'Union internationale pour l'étude scientifique de la population," Population, 4 (Oct.Dec. 1949), 749-51. The insurance industry, for which Lotka worked, was opposed to the accumulation of large social security funds.
} 
girls and middle-aged women were half those of $1900 .{ }^{47}$ In other words, prospects for rural and urban family formation and stability were transformed between 1940 and 1950 .

Woofter proved extraordinarily useful and adaptable in employing his demographic expertise to assist planners and decisionmakers; he headed up groups on new policy matters and represented the federal security administrator on interdepartmental bodies, such as the Presidential Research Board. He also advised Commerce Secretary Henry A. Wallace on transferring the Vital Statistics Division from the Census to the U.S. Public Health Service, supplied welfare data to Acting Secretary of State Dean Acheson for debates in the Economic and Social Council of the United Nations, helped the Justice Department's review of immigration policy, and regularly briefed members of Congress. He also tracked international developments, comparing notes on family composition and income with Louis Moss, director of the British Wartime Social Survey which was co-opted by the Ministry of Information, and monitored South American attempts to boost post-war immigration. ${ }^{48}$ In 1946, another major federal reorganization saw the USFSA expanded and the start of a complete re-examination of government research needs. For two years, Woofter led a comprehensive review that detailed 122 ongoing research projects, 52 planned projects, and 55 evaluations across the four USFSA sub-agencies - Public Health Service, Social Security Administration, Office of Education, and Office of Special Services - showing the new reliance by the federal and state governments on trained social scientists for the appraisal of Fair Deal policy decisions affecting every citizen, and the beginnings of a data revolution unthinkable during the Coolidge era just two decades earlier. ${ }^{49}$

\footnotetext{
47 T. J. Woofter, "Factors Sustaining the Birth Rate," American Sociological Review, 14 (June 1949), 357-66. New York Times, July 17, 1949, p.E10.

48 T. J. Woofter to Albert J. Engel, March 22, 1945, file 052, box 130, RG 235, NA; Watson Miller to Dean Acheson, May 21, 1946, file 241.3, box 197, ibid.; H. A. Wallace to Miller, file 320, box 244, ibid.; Woofter to L. Moss, April 3, 1945, file 520, box 83, ibid; Oscar Ewing to Miller, March 25, 1948, file 201, box 178, ibid. T. J. Woofter, "Saving the Lives of Good Neighbors," American Sociological Review, 12 (Aug. 1947), 420-23. 49 Woofter to Agency Research Committee, Dec. 31, 1947, file 025, box 55, RG 235.
} 
In the summer of 1949, President Truman signed the Central Intelligence Agency Act, giving the CIA more money and freedom, and reorganizing the agency in ways that enabled the poaching of specialists from across the federal government to improve gathering and analysis of data. ${ }^{50}$ In September 1949, having transformed research and project management in the Federal Security Agency, Jack Woofter moved from work dominated by public welfare to national security. He joined the CIA as chief of the Labor and Manpower (later, Population and Labor) Branch of the Economic Services Division in the Office of Research and Reports. He was hired for his skill as a research director, sociologist, and demographer, and especially his techniques for forecasting population and manpower trends, as intelligence chiefs looked for improved data on America's adversaries. ${ }^{51}$ The hiring of division and branch chiefs with academic credentials was not uncommon; hence, Woofter's recruitment for intelligence work, traceable through impersonal, declassified, and partially redacted CIA documents. $^{52}$

After World War II, as Michael Desch shows in Cult of the Irrelevant, the armed services took note of social science research and during the Cold War most government departments used social scientists in organizational and strategic planning. Desch argues that

\footnotetext{
${ }^{50}$ Rhodri Jeffreys-Jones, The CIA and American Democracy, $3^{\text {rd }}$ ed. (New Haven: Yale University Press, 2003), 59-60.

${ }^{51}$ Federal Security Agency, Notification of Personnel Action re. T. J. Woofter, Sept. 12, 1949, Woofter personnel file, NPRC. At the USFSA, Woofter received consistent "Excellent" efficiency ratings for judgement, planning, liaison, presentation, and procedural skills. He was at the top of the civil service professional salary scale (P-8, \$10,330, under the 1948 Pay Act). Through the PAA, he collaborated with Social Security Board economist Eleanor Lansing Dulles and Swedish sociologist Alva Myrdal. Population Index, 5 (April 1939), 80. 52 Jeffreys-Jones, CIA and American Democracy, 8-9. Jeffreys-Jones noted the CIA's preference for recruiting outstanding senior staff using "the principle of the New Deal's brain trust." Woofter found himself working with several people he had encountered in the Roosevelt administration. The State Department's head of Population and Labor, William T. Ham, had worked with Woofter in the BAE and the Division of Farm Population and Rural Life, as did Waller Wynne, Jr., author of several Communist state population studies for the Census Bureau. Wynne had helped with research for Landlord and Tenant on the Cotton Plantation in 1936. A. Ross Eckler, deputy director of the Census, was a statistician in the FERA.
} 
at the same time many social scientists perceived a choice between "rigor and relevance," the implication being that universities were strongholds of "rigor," whereas academics who sought "relevance" opted for government work. ${ }^{53}$ Many of those who did important studies for the government during the war, such as the psychologist Rensis Likert and the sociologist Samuel Stouffer, returned to university-based research in 1946. As a civil servant, Woofter tried to exhibit both rigor and relevance, working on population and competitive manpower assessments for strategic defense purposes, whilst maintaining his association with scholars like Stouffer through the PAA and the American Statistical Association. He nevertheless became detached from some of the debates over population control that preoccupied internationalist American demographers such as Notestein and Lorimer (although their work on wartime Europe and "emerging nations" had Cold War relevance). ${ }^{54}$

In 1947, Congress enlarged budgets and research staffing for intelligence work through the National Security Act, giving the CIA analytical functions and a military-civilian leadership intended to reduce interdepartmental rivalry. ${ }^{55}$ Dissatisfaction and tensions surrounding demographic intelligence were clear: Deputy Director of Military Intelligence Gen. Walter E. Todd complained to CIA Director Adm. Roscoe H. Hillenkoetter about the "duplication, wasted effort and needless expense" associated with the "production and dissemination of sociological intelligence in the field of population and manpower studies by various government agencies." It would, he stated, be "most efficiently and economically produced under central direction," allowing for "standardization of methods of compiling and maintaining data" for the National Intelligence Survey. Naval Intelligence Director Adm.

\footnotetext{
${ }^{53}$ Michael C. Desch, Cult of the Irrelevant: The Waning Influence of Social Science on National Security (Princeton: Princeton University Press, 2019), 89, 96-101.

54 On growth of the international population movement, see Matthew Connolly, "Seeing Beyond the State: The Population Control Movement and the Problem of Sovereignty," Past and Present, 193 (Nov. 2006), 197233, and Emily Klancher Merchant, "A Digital History of Anglophone Demography and Global Population Control, 1915-1984," Population and Development Review, 43 (March 2017), 83-117.

55 Jeffreys-Jones, CIA and American Democracy, 39-41.
} 
Thomas B. Inglis agreed, calling for "production of population and manpower studies [to be] ...coordinated by the Central Intelligence Agency,... incorporated into the basic intelligence program," and evaluated by a new "central working unit."56 The Inter-Agency Committee on Population and Manpower Studies also insisted that an "adequate inventory of the human resources of foreign countries... [was] essential to both strategic and political operations," and that the USA's commitments required systematic intelligence relevant to the "war potential of strategic countries[,] foreign aid programs and growing world-wide concerns of American foreign policy." For much of the world, including China, even basic statistics were considered "seriously incomplete or defective." It was obvious that demographic intelligence was fragmented and weak, partly because different services were demanding different data: Army Intelligence (G-2) monitored strategically important foreign military manpower; the US Air Force's Target Analysis Division gathered "minute details," from "fugitive sources" if necessary, about industry and population centers; three analysts in the State Department's Division of International and Functional Intelligence monitored key occupations, education, ethnicity, vital statistics, and disease in selected countries; and the Census Bureau gathered publicly available foreign demographic data, despite doubts about the reliability of official information. ${ }^{57}$

Woofter chaired the new Advisory Committee on International Population Statistics, which in February 1952 became the Subcommittee on Population and Manpower of the

\footnotetext{
${ }^{56}$ Walter E. Todd to Director, Central Intelligence, Sept. 25, 1947, CIA-RDP79-01143A000400010023-3, General CIA Records, CIA Library (CL), https://www.cia.gov/library/readingroom/collection/general-cia-records. Thomas B. Inglis to Director, Central Intelligence, Oct. 31, 1947, CIA-RDP79 - 01143A000400010017-0, CL. 57 "Population and Manpower Studies: Present Facilities and Requirements of the Intelligence Agencies," [annex to memo to CIA director from Inter-Agency Committee on Population and Manpower Studies, Jan. 22, 1948] CIA-RDP79-01142A000400010010-7, CL. The Chinese population baffled demographers. See Emily R. Merchant, "Prediction and Control: Global Population, Population Science, and Population Politics in the Twentieth Century" (PhD diss., University of Michigan, 2015), 210. The CIA Office of Reports and Estimates distributed raw data from central and eastern European newspapers on repatriations, marriage, births and deaths, and employment by industry and sector. See "Information from Foreign Documents or Radio Broadcasts" [Czech press, May 31-July 9, 1949], Aug. 22, 1949, CIA-RDP80-00809A0006000241136-3, CL.
} 
CIA's influential Economic Intelligence Committee (EIC), an agenda-setting forum for numerous departments, agencies, and commissions. The fortnightly Population and Manpower meetings included sociologist Charles E. Hutchinson of the USAF's Human Factors Division, Russian-born demographer Eugene Kulischer of the Library of Congress, who advised the Air Force on European labor supply distribution, Conrad Taeuber of the Census Foreign Manpower Research Office, Oscar Weigert of the Labor Department's Division of Foreign Labor Conditions, and Theodor Lit, the Labor Department's Central and Eastern European specialist. State Department objections to the merging of its own liaison committee on Soviet and Eastern European manpower with the CIA's interdepartmental demographic committee were overruled. ${ }^{58}$

Woofter co-ordinated this disparate research capacity and attempted to provide the CIA and the Joint Chiefs with a coherent picture of population and manpower changes and projections for key regions of the world. Military strength was measured in terms of American ability to overcome the Soviet Union; and yet, the administration's policy objective was the reduction of conventional forces, making the demographic projections of the Subcommittee on Population and Manpower strategically and politically significant. Woofter's remit was “to examine continuously intelligence bearing upon foreign populations and manpower for the purpose of assisting in the elimination of gaps and deficiencies in such intelligence which may be detrimental for the security of the United States." His committee

\footnotetext{
${ }^{58}$ Asst. Dir., ORE, to Chief, COAPS [State], Dec. 2, 1949, CIA-RDP79-01143A000400010001-7, CL. EIC, Subcommittee on Population and Manpower, First Progress Report (April 10, 1952 - June 10, 1952), June 11, 1952, CIA-RDP82-00283R000200130002-0, CL. EIC, Subcommittee on Population and Manpower, Oct. 1, 1952, CIA-RDP92B01090R000200120002-4, CL. See Theodore Lit, Unions in Democratic and Soviet Germany: Contrasting Roles of Labor Organizations Under Free and Totalitarian Systems in Divided Postwar Germany (Washington, D.C.: U.S. Government Printing Office, 1953). Department of State Bulletin, 13 (Oct. 21, 1945), 640-41. Hutchinson later ran the Behavioral Sciences Division of USAF's Office of Scientific Research. Desch, Cult of the Irrelevant, 102, 110-12. Kulischer documented the Holocaust and wartime migration, after fleeing Vichy France in 1941. See Eugene M. Kulischer, Europe on the Move: War and Population Changes, 1917-1947 (New York: Columbia University Press, 1948), vi; Kulischer, "Russian Manpower," Foreign Affairs, 31 (Oct. 1952), 67-78.
} 
set about evaluating all existing intelligence analyses of manpower and labor in the Soviet Union and its satellites, and commissioned new research as necessary, such as Jacob Siegel's The Population of Hungary, so as to create standardized country information sets that could underpin the CIA's National Intelligence Survey. ${ }^{59}$

Military and economic security were paramount, but softer diplomatic and humanitarian impulses also played a part. The State Department's Office of Intelligence and Research sought foreign demographic data to support human rights policies and the work of health organizations combatting epidemics (its representative on Woofter's committee, Dudley Kirk, was an expert on health and population problems in the Near East, Asia, and Africa). In the summer of 1952, in the committee's first progress report, Woofter outlined a program of highly ambitious international studies requiring masses of data on friendly and unfriendly nations:

This would include subjects such as size, composition, distribution, changes, character, and movements of the population and labor force; employment and unemployment, wages, hours and economic conditions and social welfare of labor; conditions of work; relations between employees and government and management; organizations and policies of employers and employees; hiring and recruiting of labor; public health and education. ${ }^{60}$

\footnotetext{
59 First Progress Report, June 11, 1952. Jacob S. Siegel, The Population of Hungary (Washington, D.C.: US Government Printing Office, 1958). In the same series, see also Paul F. Myers and Wayman Parker Maudlin, Population of the Federal Republic of Germany and West Berlin (1952); Waller Wynne, The Population of Czechoslovakia (1953); Maudlin and Donald S. Akers, The Population of Poland (1954); Myers and Arthur A. Campbell, The Population of Yugoslavia (1954); US Census Bureau, The Population of Mainland China, 1953 (1955); Wynne, The Population of Manchuria (1958); Samuel Baum and Jerry W. Combs, The Labor Force of the Soviet Zone of Germany and the Soviet Sector of Berlin (1959). Jean van der Tak, Jacob Siegel interview, June 21, 1988, Demographic Destinies, 1/3 (2005), 90. Jean van der Tak, Arthur Campbell interview, Feb. 16, 1988, ibid., 1/2 ((2005), 278-91. Campbell recalled (p.279), "I remember having made an age distribution for China around the time of their first census when they were not releasing very much information and you really had to make a lot of guesses about what their age distribution was."

60 First Progress Report, June 11, 1952.
} 
His completed survey of all government research on the population and manpower of the Soviet bloc highlighted the "scarcity of personnel" and numerous gaps in essential information. The Labor Department and State Department wanted more information on living standards, labor law, workers' morale in Eastern Europe, forced labor in China, and short- and long-run population and manpower estimates; the USAF, as ever, wanted more intelligence on "strategic air target areas" - such as the residential zones of industrial, construction, and government workers. ${ }^{61}$

Southeast Asia became a looming concern in August 1954, when the Geneva Accords partitioned Vietnam after the First Indochina War. Woofter and the Population and Manpower Branch produced an Intelligence Memorandum on the region for the Joint Chiefs and their intelligence directorates, and the recently-formed National Security Agency. At the time, the US Navy was helping to relocate 300,000 Vietnamese people from the North to the southern zone in Operation "Passage to Freedom," part of the movement of one million civilians, in total, encouraged by intensive CIA propaganda. ${ }^{62}$ Working largely from French materials of varying currency, Woofter estimated the populations of every province and city in Indochina, showing 30 million people still under "French Control" and less than half that number under "Communist Control." He highlighted complex ethnic groupings and colonial legacies, including stark disparities in regional development and population density; for Vietnam, in particular, he calculated that $60 \%$ of the 7 million men of military age were

\footnotetext{
61 EIC, Subcommittee on Population and Manpower, Second Progress Report (July-Dec., 1952), Dec. 15, 1952, CIA-RDP82-00283R000200130001-1, CL. Third Progress Report, July 2, 1953, and Fourth Progress Report, Aug. 23, 1954, CIA-RDP82-00283R000200130004-8, CL. On USAF's capacity for targeting population centers, see Taiwoo Kim, "Limited War, Unlimited Targets: U.S. Air Force Bombing of North Korea during the Korean War, 1950-1953," Critical Asian Studies, 44:3 (Sept. 2012), 467-92.

62 Ronald B. Frankum, Jr., suggests Operation “Passage to Freedom" paved the way to U.S. combat in Vietnam, having "established the moral obligation to ensure that those people's lives would improve under a democratic government, free from the threat of communism." See Frankum, Operation Passage to Freedom: The United States Navy in Vietnam, 1954-1955 (Lubbock: Texas Tech University Press, 2007), xx-xxi. Jonathan Nashel, Edward Lansdale's Cold War (Amherst: University of Massachusetts Press, 2005), 60-63.
} 
under Viet Minh rule. ${ }^{63}$ Thus, basic demographic and cultural information was accumulated by US intelligence and military strategists on Vietnam during the mid-1950s, but it fell far short of anything that would support planning for future intervention.

After 1955, the CIA could point to an increased number of expert staff producing intelligence on population and manpower across the federal government. The crossdepartmental Population and Manpower subcommittee was said to work well, "based on competence, good fellowship, and mutual respect," although its members continued to differ on optimal analytic methods and global priorities. ${ }^{64}$

The Eisenhower administration's New Look (NSC 162/2), formulated in October 1953 by the Joint Chiefs following the death of Stalin and a Korean truce, had declared that American "qualified manpower annually coming of military age is adequate to carry out our existing military plans," but this judgement relied heavily on accurate forecasts of foreign manpower and productivity. The government also committed itself to finding "feasible political, economic, propaganda and covert measures designed to create and exploit troublesome problems of the USSR,... and retard the growth of the military and economic potential of the Soviet bloc." 65

Cold War strategy was still hampered by "critical deficiencies" in the Census Bureau's data on Soviet industrial labor productivity and its provincial data on China and Southeast Asia. It took several years for Woofter's efforts to produce the sort of range, quality, and integration of demographic intelligence that could document Soviet

\footnotetext{
${ }^{63}$ Chief, Projects Control Staff, ORR, to Chief, Liaison Div., OCD, Sept. 2, 1954, CIARDP79T00935A000300030002-7, CL; CIA/RR IM-389, "Population and Manpower in Indochina," Sept. 1, 1954, CIA-RDP79T00935A0002000360001-3, CL.

${ }^{64}$ EIC Subcommittee on Population and Manpower to EIC Secretariat, Aug. 22, 1955, CIA-RDP8200283R000200130027-3, CL. EIC evaluation of Population and Manpower, Nov. 1, 1955, ibid. 65 John L. Gaddis, Strategies of Containment: A Critical Appraisal of American National Security during the Cold War, rev. ed. (New York: Oxford University Press, 2005), 125-96. E. Raymond Platig, "The 'New Look' Raises Old Problems," Review of Politics, 17 (Jan. 1955), 111-35. NSC 162/3, "Basic National Security Policy", Oct. 30, 1953, at https://fas.org/irp/offdocs/nsc-hst/nsc-162-2.pdf
} 
“troublesome problems." By 1958, his committee arrived at reliable indicators for productivity in Poland, Romania, Bulgaria, Hungary, Czechoslovakia, and "Soviet Germany," along with "a wide area of agreement on basic data and method." Post-war work on the Soviet Union had focused on defection and repatriation, civilian employment, the "New Lands Program," and forced labor, but the size of the population, itself, was regarded as an established fact. Major revisions were considered, therefore, after June 1956, when the USSR's new handbook, The National Economy of the USSR, gave a population figure of 200.2 million people - between 20 and 40 million fewer than most western calculations. If this was true, Woofter and his committee concluded, "It meant that the USSR had sustained much larger losses during and immediately after World War II than had been estimated." This would imply that the war's devastating effects on the birth rate and infant mortality had created "much smaller age cohorts, particularly in ages 10-15 years old." A Census Bureau specialist on the Soviet Union, Jim Brackett, later recalled, "The new data were received with shock and disbelief in our office, particularly by the emigres. ... The new data were potentially very valuable, and they had to be scrutinized carefully to determine their reliability." Brackett and his colleagues concluded that Soviet military and civilian war losses and depressed wartime birth rates caused a net population decline of 30 million. This, they realized, would mean labor shortages, with implications for the USSR's Five Year Plans and especially the Sixth and Seventh Five Year Plans (for 1956-60, and 1960-65), and suggested that "the estimates of, and Soviet policies on, forced labor, armed forces, and other non-reported categories of labor force were going to become more important than previously thought in the production of intelligence estimates of Soviet capabilities." (Regarding China, the Census Bureau and Library of Congress concentrated on urban population characteristics, 
which the CIA analysed and integrated with policy objectives in a series of studies on education, manpower, agriculture, and population control after 1956. $)^{66}$

Drawing on new Census projections of Soviet fertility and population up to 1975 and a re-assessment of age-sex distributions, Woofter issued a comparative Intelligence Memorandum, "Population Fertility in the USSR and the US." He noted entirely opposite trends in the two superpowers: Soviet fertility was shown dropping by $18-20 \%$ after 1940 before stabilizing, whereas US fertility had risen between $37 \%$ and $55 \%$ and was continuing to increase. The US wartime baby boom and the "abnormally small number of war babies in the USSR" produced dramatically different labor force scenarios for the superpowers in the 1960s, in which the USSR would be required to shift farm workers into industry, increase productivity, direct school-leavers into key occupations, postpone retirement for elderly workers, and reduce numbers in the armed forces. The significant Soviet advantage over the USA in terms of men of military age (a gap of some 7 million in 1956) was expected to fall to just 3 million by $1975 .{ }^{67}$ These were all vital inferences for defense policymakers.

The clear value of demography to long-term security planning saw seventy government personnel engaged in "economic intelligence and related economic research" concerning foreign population and manpower studies by 1958; fifty of them worked on the Sino-Soviet bloc and all were in agencies represented on Woofter's committee. In a move

\footnotetext{
66 EIC evaluation of Population and Manpower, Nov. 1, 1955, CIA-RDP82-00283R000200130027-3, CL. Annual Review of Activities...EIC Subcommittee on Population and Manpower, Aug. 8, 1956, CIA-RDP8200283R000200130026-4, CL. Annual Review of Activities..., EIC Subcommittee on Population and Manpower, Sept. 13, 1957, CIA-RDP82-00283R000200130025-5, CL. Previous estimates relied on work by demographer Frank Lorimer. See Lorimer, The Population of the Soviet Union: History and Prospects (Geneva: League of Nations, 1946). The USAF and the Air Research Division of the Library of Congress produced annual demographic estimates for China and the Soviet Union and began an urban and regional series of 152 studies and a "Target Data Inventory." Jean van der Tak, James Brackett interview, March 29, 1988, Demographic Destinies, 2 (2005), 79-80; Jacob Siegel interview, ibid., June 21, 1988, ibid, 1/3 (2005), 90.

${ }^{67}$ Chief, Projects Control Staff, ORR, to Asst. Director, Research and Reports, Jan. 8, 1957, CIARDP79T00935A000300030002-7, CL; CIA/RR IM-445, "Population Fertility in the USSR and the US, 1940-55," Jan. 21, 1957, CIA-RDP79T00935A0002000360001-3, CL. On challenges in estimating Soviet capabilities and spending, see W. T. Lee, "The Shift in Soviet National Priorities to Military Forces, 1958-85," Annals of the American Academy of Political and Social Science, 457 (Sept. 1981), 46-66. Lee worked for the CIA, 1951-64.
} 
consistent with Eisenhower's second term attempts at open communication with the Kremlin, the State Department proposed exchange visits by Russian and American demographers and census officials. Although such dialogue on population studies did not, in fact, commence until the late 1960s, it was not an outlandish suggestion in 1958; in that year, US experts on social security visited the USSR and hosted a Soviet delegation in return, and similar exchanges involving print and radio journalists, mining engineers, and agricultural experts took place. ${ }^{68}$ When Woofter's decade of secret population studies ended with his retirement in 1958, aged sixty-five, his CIA branch and his cross-departmental committee were coordinating demographic expertise in three areas vital to Eisenhower's foreign policy: war planning, propaganda, and economic competition.

Firstly, strategic air planning for a preferred "massive retaliation" through a second strike required robust data on the location, size, and concentrations of the civilian population and likely enemy losses. Less favored strategies also relied on demographic data: for example, according to advice given to presidential military adviser Gen. Maxwell Taylor by his Air Force staff assistant in 1961, another Berlin crisis might require a low-altitude first strike against military targets, "to eliminate Soviet intercontinental threat and ... minimize damage to Soviet population, industry and governmental authority.... This kind of attack, employing air burst 1MT weapons, might result in Soviet casualties of less than 1 million and probably not more than 500,000." ${ }^{\prime 69}$ Such assumptions, reliable or otherwise, were impossible without the work of government demographers.

\footnotetext{
68 EIC Minutes, July 6, 1958, extract, CIA-RDP82-00283R000200130024-6, CL. Annual Report... on Population and Manpower for Fiscal Year 1958, Aug.2, 1958, CIA-RDP82-000283R000200130022-8, CL. The next Soviet census date was January 1959; the US Census was in April 1960. Frederick Chase Barghoorn, The Soviet Cultural Offensive: The Role of Cultural Diplomacy in Soviet Foreign Policy (Princeton: Princeton University Press, 1960), 268-335. Yale Richmond, Cultural Exchange and the Cold War: Raising the Iron Curtain (University Park: Penn State University Press, 2003), 70-71. Elmer Plischke, "Eisenhower's "Correspondence Diplomacy" with the Kremlin - Case Study in Summit Diplomatics," Journal of Politics, 30 (Feb. 1968), 137-59.

${ }^{69}$ Maj. William Y. Smith to Gen. Maxwell Taylor, Sept. 7, 1961, Kennedy Library, at National Security Archive, https://nsarchive2.gwu.edu/NSAEBB/NSAEBB56/
} 
Secondly, there was thought to be immense propaganda value in showing the gulf between occupational freedoms, labor productivity, and living standards in the USA and in the USSR. ${ }^{70}$ Thirdly, it was essential for American planning purposes to gather intelligence on the Soviet Union's capacity to commit sufficient manpower to its infrastructure and output objectives, and sustain its military presence in the communist bloc. This forecasting capacity grew out of Woofter's work in laying the foundations for Census Bureau and CIA studies of Soviet and other foreign populations for the duration of the Cold War. Annually revised demographic studies, such as "Population of the Communist Countries, Selected Years, 19381980," fed into the National Intelligence Survey and were adapted for the CIA's "Population Wall Chart," which itself evolved into the National Basic Intelligence Factbook. (This compilation was declassified in 1971 and renamed World Factbook in 1981.) By the mid1960s, standardized demographic intelligence was embedded in national security conversations, so that the role Woofter initially assumed in the CIA, adjudicating between agencies determined to protect their own data and methods, was no longer required. The Subcommittee on Population and Manpower was wound up by the EIC in 1966 and its functions given to the Subcommittee on General Economic Analysis, but Woofter's work during the 1950s left a legacy of coherence and consistency in a vital area of classified government research. ${ }^{71}$

IV

\footnotetext{
70 Nicholas J. Cull, The Cold War and the United States Information Agency: American Propaganda and Public Diplomacy, 1945-1989 (New York: Cambridge University Press, 2008), 104-119. Scott Lucas, Freedom's War: The US Crusade Against the Soviet Union, 1945-56 (Manchester: Manchester University Press, 1999), $202-203$. ${ }^{71}$ See, for example, James W. Brackett, Projections of the Population of the USSR, by Age and Sex: 1964-1965 (Washington, D.C.: U.S. Government Printing Office, 1964). Annual Report... on Population and Manpower for Fiscal Year 1958, June 10, 1958, CIA-RDP82-00283R000200130017-4, CL. Recommendation for Abolition of Subcommittee on Population and Manpower, March 22, 1966, CIA-RDP82-00283R000200210082-3, CL.
} 
Jack Woofter's first job after graduate school in 1913 was three years of fieldwork for a study of southern black education, paid for by a New York philanthropic fund and published by the U.S. Bureau of Education. Like other reports on social conditions in the Progressive era, it was welcomed by a federal administration that was happy to benefit from the resources and expertise of reform-minded citizens, but not inclined to investigate regional racial conditions for itself, let alone intervene. ${ }^{72}$ Twenty years on, when the US government was more fully engaged with social science research during the Great Depression, it relied on directors of research like Woofter. These were scholars who willingly left academic life for work that was directly relevant to urgent social problems and reforms, despite the limited recognition and career progression on offer and the susceptibility of programs to changes in policy. Woofter's own career was to differ from that of many academics who worked in Washington in the 1930s and 1940s, in that his skills were constantly in demand and were highly transferable to new branches of government, and the attraction of new challenges may explain his decision not to revert to a senior career in education.

In 1957, on the brink of retirement, Woofter published a reflection on the growing movement for civil rights and his own experiences as a campaigner for interracial cooperation and the eradication of lynching in the 1920s. It showed that, while his racial outlook had not altered significantly, he retained his optimism and faith in a strand of cautious southern white liberalism that linked men and women like Will Alexander, Lucy Randolph Mason, and Howard Odum - people committed to social justice, who reacted to the Great Depression with what southern journalist Ralph McGill called a "mighty surge of discussion, debate, self-examination, confession and release." 73 Hundreds of trained social

\footnotetext{
72 Thomas Jesse Jones, ed., Negro Education: A Study of the Private and Higher Schools for Colored People in the United States, 2 vols. (Washington, D.C.: U.S. Government Printing Office, 1917).

73 T. J. Woofter, Southern Race Progress: The Wavering Color Line (Washington, D.C.: Public Affairs Press, 1957); Ralph McGill, The South and the Southerner (Boston: Little, Brown, 1964), 159.
} 
scientists flocked to Washington, D.C., or state capitals to enter government service during the 1930s and 1940s, sensing a duty during a national emergency to equip politicians and planners with policy-oriented research. Woofter's career offers a clear example of an unusually durable and adaptable Progressive activist whose skills and evolving interests chimed with society's needs during the series of domestic and international crises that the United States faced between the birth of social security and the onset of the national security state.

For several decades after World War I, many public officials and academics in the United States were skeptical about the long-term benefits of close collaboration between policymakers and social scientists, but researchers like Jack Woofter, whose role ultimately, as Richard Nathan has put it, was that of "amplifying issues and elucidating options," could see the possibilities of policy-oriented scholarship and its contribution to the evolution of federal power. ${ }^{74}$ Woofter's shifting administrative status and the secrecy surrounding his final years in Washington may have contributed to an undeserved anonymity, but he was recognized by his fellow professionals for his skill and wisdom in co-ordinating major research programs and for his own work on race, farm economics, welfare, and demography. His clear and comprehensive reports - typified by Landlord and Tenant on the Cotton Plantation - his scholarship on the applications of research, and the methodological rigor of his projections concerning social programs and national security - were expressions of one of the most useful American social science careers in the middle years of the $20^{\text {th }}$ century.

\footnotetext{
${ }^{74}$ Richard P. Nathan, Social Science in Government: The Role of Policy Researchers (Albany, NY: Rockefeller Institute Press, 2000), 3, 5. On the shifting relationship between American social science and government, see Henry W. Riecken, "The Federal Government and Social Science Policy in the United States," in A. B. Cherns, R. Sinclair, and W. I. Jenkins, eds., Social Science and Government: Policies and Problems (London: Tavistock, 1972), 173-90.
} 
T. J. Woofter and Government Social Science Research During the New Deal, World War II, and the Cold War.

The writings of Thomas Jackson (Jack) Woofter, Jr. (1893-1972), one of the few southern white Progressives whose main focus was on race relations, are frequently cited by American historians, but the extent of his career and connections in government remain little known. After playing a central role in the interracial cooperation movement in the 1920s and becoming a pioneering sociologist, he directed federal government research on rural relief in the 1930s, advised on the expansion of social security during and after World War II, and coordinated intelligence and projections on the manpower and productivity of America's adversaries during the Cold War. Through his contributions to the design and delivery of essential programs for key agencies, and collaborations with notable officials, Woofter assisted vital transitions in government policy and social attitudes between 1930 and 1960 .

He also helped to maintain a social science presence in policymaking circles during a period when it was under threat. The in-house, as opposed to philanthropically-funded, academic base of government policymaking began with the Department of Agriculture's engagement with rural sociology after World War I, and expanded during the Great Depression and World War II. After 1945, social science research in government was heavily reduced, but Woofter was among those who continued to provide vital expertise in recently-formed agencies responsible for meeting domestic and global obligations of the United States. Not until the year Jack Woofter retired, in 1958, was an Office of Social Sciences finally created within the National Science Foundation, with an initial budget of $\$ 750,000$, rising to $\$ 10$ million in 1965 , as a new chapter began in the relationship between government and the social sciences. ${ }^{1}$

\footnotetext{
${ }^{1}$ Olaf F. Larson and Julie N. Zimmerman, Sociology in Government: The Galpin-Taylor Years in the U.S. Department of Agriculture, 1919-1953 (University Park: Pennsylvania State University Press, 2003), passim;
} 
Woofter's scholarship on African American education, migration, urban race relations, rural sociology, farm economics, social security, and demography was at the cutting edge of those disciplines and specialisms. His publications are widely acknowledged in numerous studies, but his ability to consolidate and manage research data for official purposes has been largely overlooked. He was a skilled co-ordinator of government research and he was brilliant at synthesizing and presenting complex trends and relationships for specialists, policymakers, legislators, journalists, and general readers. ${ }^{2}$ Throughout, he displayed the instincts of a liberal reformer, supporting expansion of the federal government and searching as he put it, for "the human elements" in the interplay between powerful economic forces and interventionist policy. ${ }^{3}$

This article is structured around three key phases of Woofter's life as a government researcher - the study of rural life during the New Deal, the forecasting of social security and welfare requirements during the 1940s, and the confidential analysis of international demographic data during the Cold War. It assesses his significance and contribution as a social science research director and adviser who communicated widely on major problems and promoted public understanding of government policies during a critical period in modern history. It also illustrates the kind of unpredictable career paths open to academics who were

Martin Bulmer, ed., Social Science Research and Government: Comparative Essays on Britain and the United States (Cambridge: Cambridge University Press, 1987), 2-3. See also Jess Gilbert, Planning Democracy: Agrarian Intellectuals and the Intended New Deal (New Haven: Yale University Press, 2015), 48. Gilbert describes the U.S. Bureau of Agricultural Economics in the 1920 s as "the largest social-science research agency in the federal government and perhaps the largest body of economic experts in the Western world."

${ }^{2}$ For examples of work noting Woofter's research, see Dewey W. Grantham, The South in Modern America: A Region At Odds (New York: HarperCollins, 1994), 147; Andrew Wiese, "Blacks in the Suburban and Rural Fringe," in Henry Louis Taylor, Jr., and Walter Hill, eds., Historical Roots of the Urban Crisis: African Americans in the Industrial City, 1900-1950 (New York: Garland, 2000), 158, 166-70; Anthony J. Badger, Prosperity Road: The New Deal, Tobacco, and North Carolina (Chapel Hill: University of North Carolina Press, 1980), 240; W. Fitzhugh Brundage, Under Sentence of Death: Lynching in the South (Chapel Hill: University of North Carolina Press, 1997), 7; Lewis M. Killian, White Southerners (New York: Random House, 1970), 93-94; Mark Lowry II, "Population and Race in Mississippi,1940-1960," Annals of the Association of American Geographers, 61 (Sept. 1971), 576, 588; Charles S. Aiken, The Cotton Plantation South since the Civil War (Baltimore: Johns Hopkins University Press, 1998), 35-39, 52-53. I wish to thank the anonymous JPH reviewers for all their comments.

${ }^{3}$ T. J. Woofter, Jr., Landlord and Tenant on the Cotton Plantation (Washington, D.C.: Works Progress Administration, 1936), xvii. 
willing to be deployed as required in public service, and the bureaucratic utility of the adaptable individual with key technical skills and the ability to cross agency boundaries as crises arise.

Born in 1893 and raised in Athens, Georgia, Woofter gained his BA degree from the University of Georgia aged nineteen; after a year of graduate study, he spent fifteen years as a researcher, organizer, publicist, and antilynching activist for the southern interracial cooperation movement, interrupted by two years as a military statistician in the American Expeditionary Force's headquarters and a ground-breaking $\mathrm{PhD}$ at Columbia University on black migration. This immersion in wartime planning and rural demographic projection fostered in Woofter a lasting faith in the power of skilfully presented quantitative data. In 1927, he left the Commission on Interracial Cooperation (CIC) in Atlanta to join Howard W. Odum's Institute for Research in Social Science at the University of North Carolina (UNC) at Chapel Hill. With his salary and research initially funded by the Laura Spelman Rockefeller Memorial, he studied African American demographics and urban conditions, the "evils attending the farm tenant system and conditions in the courts," life on the seas islands, and sub-regional agricultural challenges, such as those faced by tobacco growers. ${ }^{4}$

\footnotetext{
${ }^{4}$ T. J. Woofter, Jr., Negro Migration: Changes in Rural Organization and Population of the Cotton Belt (New York: W. D. Gray, 1920). His PhD was the first correlational study to use multiple regression techniques, according to Stephen P. Turner, "The World of the Academic Quantifiers: The Columbia University Family and its Connections," in Martin Bulmer et al., eds., The Social Survey in Historical Perspective, 1880-1940 (New York: Cambridge University Press, 1991), 283. T. J. Woofter, Jr., and Madge Headley, Negro Housing in Philadelphia (Philadelphia: Institute of Social and Religious Research, 1927). T. J. Woofter, Jr., ed., Negro Problems in Cities (Garden City, NY: Doubleday, Doran, 1928). T. J. Woofter, "The Negro and the Farm Crisis," Social Forces, 6 (June 1928), 615-20. T. J. Woofter, "Race in Politics: An Opportunity for Original Research," Social Forces, 7 (March 1929), 435-38. T. J. Woofter, Jr., Black Yeomanry: Life on St. Helena Island (New York: Henry Holt, 1930). T. J. Woofter, Jr., The Plight of Cigarette Tobacco (Chapel Hill: University of North Carolina Press, 1931). T. J. Woofter, Jr., "Race Relations," American Journal of Sociology, 36 (May 1931), 1039-44. T. J. Woofter and Edith Webb, "A Reclassification of Urban-Rural Population," Social Forces, 11 (March 1933), 34851. T. J. Woofter, "Common Errors in Sampling," Social Forces, 11 (May 1933), 521-25. T. J. Woofter, "Difficulties in Measuring Racial Mental Traits," Social Forces, 13 (March 1935), 415-18. On his career before
} 
At UNC, he produced a report for President Herbert Hoover's commission on African Americans in the US economy and was criticized by W. E. B. Du Bois for placing insufficient weight on racial discrimination. He also contributed a sociological study, "The Status of Racial and Ethnic Groups," to Hoover's Research Committee on Social Trends. In 1933, Odum commended Woofter to Tennessee Valley Authority Director Arthur E. Morgan as "a very genuine spirit as well as a good social statistician," leading to a series of impact studies. ${ }^{5}$ Woofter also improved Odum's regional model for southern studies. Claiming there were "many Souths," he ignored state boundaries, dividing 976 south-eastern counties into twenty-seven seemingly homogenous clusters - the smallest with four counties, the largest with 122 - believing that social and cultural bonds grew from shared geography. Using labels such as "Mining," "Red River," "Blue Grass," "Northern Piedmont," and "SemiTropical," he highlighted local rates of literacy, tenancy, employment, and the ownership of telephones and cars, along with land values and racial composition, and claimed his groupings assisted "practical planning of social programs [and] research into the characteristics of the region." Decades later, they were still used by social scientists. ${ }^{6}$

\section{0, see Mark Ellis, Race Harmony and Black Progress: Jack Woofter and the Interracial Cooperation} Movement (Bloomington: Indiana University Press, 2013).

5 T. J. Woofter, “A Study of the Economic Status of the Negro," June 1930, file 377, series I, frames 253-375, reel 19, Papers of the Commission on Interracial Cooperation, 1919-1944, Woodruff Library, Atlanta University Centre. T. J. Woofter, Jr., "The Status of Racial and Ethnic Groups," in William F. Ogburn, Howard W. Odum, and Edward E. Hunt, eds., Recent Social Trends in the United States, vol. 1 (New York: McGraw-Hill, 1933), 553601; and T. J. Woofter, Jr., Races and Ethnic Groups in American Life (New York: McGraw-Hill, 1933). T. J. Woofter, "The Tennessee Valley Regional Plan," Social Forces, 12 (March 1934), 329-38; T. J. Woofter, "The Tennessee Basin," American Journal of Sociology, 39 (May 1934), 809-17. Woofter correspondence re. "The Tennessee Valley Study, 1933-1934," in Howard W. Odum Papers, Southern Historical Collection (SHC), Wilson Library, University of North Carolina, Chapel Hill (UNC). Morton Sosna, In Search of the Silent South (New York: Columbia University Press, 1977), 61-63. W. E. B. Du Bois, "Woofterism," Crisis, 39 (March 1931), 81-83. Du Bois wanted to "restore to the American Negro his rightful hegemony of scientific investigation and guidance of the Negro problem," and disliked how easily white academics gained support for race studies. Du Bois to Ira DeA. Reid, April 14, 1939, in Herbert Aptheker, ed., The Correspondence of W. E. B. Du Bois, Volume II, Selections, 1934-1944 (Amherst: University of Massachusetts Press, 1976), 187-91.

6 T. J. Woofter, Jr., "The Subregions of the Southeast," Social Forces, 13 (Oct. 1934), 43-50. See also Woofter's critical review of Odum and Moore, American Regionalism (1938) in Rural Sociology, 4 (June 1939), 250-52, and Rupert Bayless Vance, Regionalism and the South: Selected Papers of Rupert Vance, ed. John Shelton Reed and Daniel Joseph Singal (Chapel Hill: University of North Carolina Press, 1982), 189-90. 
During the early 1930s, like other rural sociologists and economists in the South and West, Jack Woofter studied distressed communities and rural relief programs (in 1934, 1.7 million families were dependent on relief). He was critical of the conflicting agendas and methods of the agencies attempting to help farmers in the first two years of the New Deal; nevertheless, in March 1935, he agreed to a temporary transfer to the Federal Emergency Relief Administration (FERA) and eventually chose to remain in what he called "the mad house which is Washington" until he retired. ${ }^{7}$

Woofter worked on sharecropping in the Rural Unit of the FERA's Research Section and in September 1935 became Coordinator of Rural Research. He oversaw the work of rural social workers and state research supervisors in the thirty-one cooperating states and collaborated with sociologists in the long-established Division of Farm Population and Rural Life (DFPRL), part of the Department of Agriculture's Bureau of Agricultural Economics (BAE), led by Carl C. Taylor. According to its historians, DFPRL had been "literally left out of the action during the First Agrarian New Deal," when an array of new schemes was launched in response to the farm crisis. ${ }^{8}$ Woofter saw the South as the main problem, but his FERA remit was national; in 1935, he chaired conferences of FERA officials from eight western states in Salt Lake City and met supervisors from nine western drought states in Omaha. One of his first steps was to improve methods for collecting and sharing data on

\footnotetext{
${ }^{7}$ T. J. Woofter, "Southern Population and Social Planning," Social Forces, 14 (Oct. 1935), 16-22; T. J. Woofter, "Rural Relief and the Back-to-the-Farm Movement," Social Forces, 14 (March 1936), 382-88. News-Chronicle [Shippensburg, PA], April 14, 1936, p.4. Woofter approved of the Reconstruction Finance Corporation and the homestead element of the National Industrial Recovery Act. Woofter to Howard Odum, April 5, 1935, folder W-General, box 42, Odum Papers, SHC, UNC.

8 "State Supervisors of Rural Research" folder, box 2, and Progress Reports, March 4-9, March 11-16, 1935, in "Weekly Progress Reports, 1935" folder, box 18, Records of the Division of Social Research, 1933-1942, Records of the Works Progress Administration, Record Group (RG) 69, National Archives II (NA), College Park, MD. Carl C. Taylor, "The Beginnings of Rural Social Studies in the United States Department of Agriculture," Rural Sociology, 4 (June 1939), 219-28. Larson and Zimmerman, Sociology in Government, 195-97, 220-21. See also Richard S. Kirkendall, Social Scientists and Farm Politics in the Age of Roosevelt (Columbia: University of Missouri Press, 1966). On FERA and regional social workers, see Josephine C. Brown, "Rural Families on Relief," Annals of the American Academy of Political and Social Science, 176 (Nov. 1934), 90-94.
} 
relief applicants, employable recipients, rural women, African American youth, "stranded village and small town communities," education, and drought. ${ }^{9}$

In May 1935, the Resettlement Administration was formed, as the New Deal developed longer-term strategies; by December, emergency grants had ended and the FERA was replaced by the Works Progress Administration (WPA), providing work for unemployed adults, and by the Social Security Board, delivering assistance and insurance under the Social Security Act. Woofter transferred to the WPA as its principal agricultural economist and chief of Rural Surveys, supervising studies of rural life and distributing funds to state colleges. He also devised methods for calculating accurately the number of citizens and households receiving relief or emergency employment, showing this peaking at 27.5 million people in 7.8 million households during the winter of 1933-34, and settling at 17 million people in 5.5 million households in $1938 .^{10}$

In all, Woofter oversaw production of fourteen substantial government studies, writing several himself, including Landlord and Tenant on the Cotton Plantation (1936) and a follow-up, The Plantation South, 1934-1937 (1940). Described as "one of the classics on the subject," Landlord and Tenant on the Cotton Plantation was part of an outpouring of academic, official, literary, photographic, cinematic, and journalistic work on American farm tenancy and its place in the wider depression. ${ }^{11}$ Starting in June 1935, Woofter led a team of

\footnotetext{
9 "T. J. Woofter" folder, box 2, and Progress Report, Oct. 7-12, 1935, in "Weekly Progress Reports" folders, box 19, RG 69, NA. Ogden (Utah) Standard-Examiner, Oct. 25, 1935, p.16; Salt Lake Tribune, Oct. 26, 1935, p.18, and Oct. 27, 1935, p.54. On FERA research, see Howard B. Myers, "The General Development and Present Status of the FERA Research Program," Social Forces, 13 (May 1935), 477-81, and Dwight Sanderson, "The Contribution of Research to Rural Relief Problems," ibid., 482-85.

${ }^{10}$ T. J. Woofter, Jr., and T. E. Whiting, "Households and Persons Receiving Relief or Assistance," Journal of the American Statistical Association, 33 (June 1938), 363-72. In 1941, Woofter and Whiting, a WPA statistician, produced the first comprehensive summary on all New Deal agencies and programs. Theodore E. Whiting and T. J. Woofter, Jr., Summary of Relief and Federal Work Program Statistics, 1933-1940 (Washington, D.C.: U.S. Government Printing Office, 1941).

${ }^{11}$ Charles Price Loomis and Joseph Allan Beegle, A Strategy for Rural Change (New York: Schenkman, 1975), 495. For examples of WPA Division of Social Research monographs and other reports, see Waller Wynne, Jr., Five Years of Rural Relief (1938); A. R. Mangus, Changing Aspects of Rural Relief (1938); R. S. Kifer and H. L. Stewart, Farming Hazards and the Drought Area (1938); E. A. Schuler, Social Status and Farm Tenure: Attitudes and Social Conditions of Corn Belt and Cotton Belt Farmers (1938); Carl C. Taylor, Helen W. Wheeler, and E. L.
} 
local enumerators and DFPRL sociologists in detailed surveys of 646 plantations, punchcarding 4,500 tenants' schedules for the 1934 crop year and creating an unprecedented picture of plantation life, finances, land tenure, education, mobility, housing, and health in seven cotton growing south-eastern states. Only half the tenants in the South worked in a cotton plantation setting, but Woofter insisted that persistent "plantation customs and ideology set the pattern for relationships..., and the plantation stands out as the basis for a hereditary oligarchy in southern community life." Chronic poverty, low prices, constant debt, recurrent sickness, incompetent land ownership, and soil erosion were found everywhere, with African American tenants experiencing the worst conditions. ${ }^{12}$ The report, with 170 figures and tables, was not formally transmitted by the WPA until the end of 1936, but in the summer of 1935 the press got wind of it, resulting in reports that "Woofter's private opinion" was that the Agricultural Adjustment Administration (AAA)'s controversial acreage reduction schemes had made conditions worse for tenants and croppers, increasing their eviction rate and boosting the incomes of landlords. ${ }^{13}$ This attack on a flagship program of the first New Deal ensured that Woofter's study attracted wide attention and contributed to a surge in public and congressional sympathy toward impoverished tenants; the press also picked up on Woofter's view that there were no easy, short-term solutions to the tenancy problem and his implied skepticism about the recently-introduced Bankhead-Jones Farm Tenant bill. (The Bankhead-Jones bill, authorizing the federal government to take over and

Kirkpatrick, Disadvantaged Classes in American Agriculture (1938); and Carle C. Zimmerman and Nathan L. Whetten, Rural Families on Relief (1939); Joseph Gaer, Toward Farm Security: The Problem of Rural Poverty and the Work of the Farm Security Administration (1941). For non-government rural poverty studies, see Charles S. Johnson, Shadow of the Plantation (Chicago: University of Chicago Press, 1934); Johnson, Edwin R. Embree, and W. W. Alexander, The Collapse of Cotton Tenancy (Chapel Hill: University of North Carolina Press, 1935); Rupert B. Vance, How the Other Half is Housed: A Pictorial Record of Subminimum Farm Housing in the South (Chapel Hill: University of North Carolina Press, 1936); Arthur Raper and Ira DeA. Reid, Sharecroppers All (Chapel Hill: University of North Carolina Press, 1941); James Agee and Walker Evans, Let Us Now Praise Famous Men (Boston: Houghton Mifflin, 1941).

${ }^{12}$ Woofter, Landlord and Tenant on the Cotton Plantation, xviii, passim. On official sentiment, see Donald $\mathrm{H}$. Grubbs, Cry from the Cotton: The Southern Tenant Farmers' Union and the New Deal (Chapel Hill: University of North Carolina Press, 1971), 136-61.

${ }^{13}$ Express [Lock Haven, PA], Aug. 9, 1935, p.8 
restore damaged land on behalf of tenants, was finally enacted in June 1937, when the Resettlement Administration's projects were absorbed by the Department of Agriculture's new Farm Security Administration). ${ }^{14}$

The director of the WPA, Harry Hopkins, saw Woofter's report as a useful stick with which to beat the AAA and its cautious administrator, Chester C. Davis. This divide between the AAA and the WPA's anti-elitist approach was aired publicly at an ill-tempered convention of fifty rural sociologists and other experts hosted by Howard Odum at Chapel Hill in June 1936. The South, they agreed, was at "a new crossroads of crisis.” Addressing the convention, Woofter expressed frustration at disjointed federal farm policies that rewarded landowners and rural businesses and prioritized highways and dams over education. He called for a "national educational plan... and revitalization of the educational system from the kindergarten to the university," and issued a warning: "This accumulation of a great mass of rural population with limited cultural opportunities creates a hotbed of smoldering discontent which at any instant can break out into revolt against the status quo." Another rural sociologist on secondment to Washington, Barnett Osborne Williams of Clemson Agricultural College, accused the government of neglecting "the human factors" in attempting to fix rural America - he had spoken to Secretary of Agriculture Henry A. Wallace about the plight of the farm family "and got no response from him. I argued the importance of the sociological approach, but he thought it would not be scientific. I told him

\footnotetext{
${ }^{14}$ Report of Activities, Jan. 2, 1937, Misc. Memoranda, 1935-37 folder, box 3, Central Office Records, RG 69, NA. Pittsburgh Press, Oct. 4, 1936, p.2; New York Times, Dec. 20, 1936, p.8; Washington Post, Dec. 20, 1936, p.M5; St. Louis Post-Dispatch, Dec. 20, 1936, p.21; Shreveport [LA] Times, Dec. 21, 1936, p.6. On the BankheadJones Farm Tenancy Act, see Sidney Baldwin, Poverty and Politics: The Rise and Decline of the Farm Security Administration (Chapel Hill: University of North Carolina Press, 1968), 126-92. Franklin D. Roosevelt, "A Message to Congress on Farm Tenancy. February 16, 1937," in Samuel I. Rosenman, ed., Public Papers and Addresses of Franklin D. Roosevelt: 1937 Volume, The Constitution Prevails (New York: Macmillan, 1941), 8085. Academic reviews of Landlord and Tenant were largely positive (e.g., reviews by Edgar T. Thompson in American Journal of Sociology, 43 (May 1938), 1007-1009, and C. O. Brannen in Rural Sociology, 4 (June 1939), 257-58). Radical scholars demanded a more explicit critique of the AAA and accused government researchers of being "politically timid" (e.g., review by Louise Pearson Mitchell in Journal of Negro History, 22 (July 1937), 350-53).
} 
you could work from the people to the land or from the land to the people. But he could be neither convinced nor interested." These outbursts at Chapel Hill by government officials appeared verbatim in the press. ${ }^{15}$

During 1938-39, Woofter co-wrote The Plantation South, 1934-1937, assessing the impact of the depression and the effectiveness of consequent New Deal measures. During the high-yielding 1937 crop year, he instructed his state supervisors to repeat the 1934 surveys in 246 of the original plantations and found that over the previous three years planters had increased their landholdings, work animals, cultivated acreage, and yields per acre (especially of cotton), all of which ran counter to the AAA's policy of preventing overproduction to sustain farm prices. There were now fewer renters and croppers, and more laborers. Planters' debts were down and their net incomes were up, whereas tenants' average cash income increases (up from $\$ 263$ in 1934 , to $\$ 300$ in 1937) had been wiped out by their new debts. Winter hardship was compounded by substandard diets, housing, and healthcare, while the WPA's work programs offered too few jobs for the underemployed. The President's Committee on Farm Tenancy, chaired by Wallace, had endorsed the BankheadJones proposals for reducing permanent and dependent tenancy, requiring proper leases, and helping resourceful tenants to become landowners, but these gradualist policies were still unimplemented. Clearly, Woofter concluded, "Much remains to be done."16

The implicit radicalism of Landlord and Tenant and The Plantation South was fully embraced by the WPA and in the summer of 1938, at Hopkins's suggestion, Woofter popularised their message by writing Seven Lean Years (1939) with Ellen Black Winston, a North Carolinian junior member of the WPA's Division of Research. Unlike Woofter's

\footnotetext{
${ }^{15}$ New York Times, June 19, 21, 22, 1936, p.13. Christian Science Monitor, June 24, 1936, p.2. Pittsburgh Courier, June 27, 1936, p.2.

${ }^{16}$ William C. Holley, Ellen Winston, and T. J. Woofter, Jr., The Plantation South, 1934-1937 (Washington, D.C.: U.S. Government Printing Office, 1940), iii, xi, xv-xxii.
} 
official publications, which were put out by the U.S. Government Printing Office, Seven Lean Years was published by the University of North Carolina Press and aimed at a white general audience. Hopkins saw it as useful propaganda for rural relief and an opportunity to contrast the Roosevelt and Hoover administrations. The book was an ominous "national analysis" of farm life from 1931 to 1937, during which the FERA, the Resettlement Administration and the WPA had spent $\$ 3.5$ billion in attempting to relieve distress in rural communities, and the USDA spent a further $\$ 10$ billion on price-fixing and direct grants. ${ }^{17}$

By synthesizing the findings of the FERA and WPA research divisions, Woofter and Winston intended to offer "a nontechnical summary of the fundamental aspects of maladjustment in rural areas and outline methods for the reconstruction of rural life which should prevent the recurrence of needless distress." Instead of an agronomical survey, they declared, Seven Lean Years would take a "humanitarian" look at extreme rural poverty without "sentimentalism and political claptrap," but it was nevertheless the most polemical thing Woofter ever wrote. The authors set out their "abiding conviction that it is important to the national welfare that positive programs of agrarian and social reform be vigorously pursued." They called for permanently raised living standards through "very fundamental planning" and programs that would have benefited farming long before the depression. ${ }^{18}$ They chose sixteen WPA photographs to contrast the bleakness of "Displaced Tenants," "A

\footnotetext{
${ }^{17}$ Winston paid tribute in his obituary to Woofter's mentoring of junior staff. Ellen Winston, "Thomas Jackson Woofter, 1893-1972," Footnotes, 1 (Jan. 1973), 6. Her PhD on poverty in southern sub-regions was supervised by University of Chicago demographic sociologist William F. Ogburn. In 1944, she became North Carolina commissioner of public welfare and, in 1963, the first U.S. commissioner of welfare in the Department of Health, Education, and Welfare. Eileen Boris, "Ellen Black Winston: Social Science for Social Welfare," in Michele Gillespie and Sally G. McMillen, eds., North Carolina Women: Their Lives and Times, Volume 2 (Athens: University of Georgia Press, 2015), 238-61. In 2002, disclosures about sterilization under the Eugenics Board of North Carolina, which Winston chaired, led to a gubernatorial apology. See Johanna Schoen, Coercion and Choice: Birth Control, Sterilization, and Abortion in Public Health and Welfare (Chapel Hill: University of North Carolina Press, 2005), 75-139, 241-50. John Railey, Kevin Begos, and Danielle Deaver, "Little Notice and Less Explanation," Winston-Salem Journal, Feb. 16, 2003, at http://extras.journalnow.com/againsttheirwill/parts/epilogue/storybody8.html ${ }^{18}$ T. J. Woofter, Jr., and Ellen Winston, Seven Lean Years (Chapel Hill: University of North Carolina Press, 1939), v, vi-vii, 2
} 
Large Relief Family on Poor Land," tented migrant camps, soil erosion, and dust storms, with optimistic images of rural schools and clinics, smiling young laborers on federal projects, a "Rehabilitated" farmer with hog carcasses in his well-stocked storeroom, and "The Millionth WPA Pupil” studying farming methods.

All the photographs and almost all the family case histories included were of white people, despite the desperate situation of millions of rural African Americans. Revealingly, the book's longest reference to black farmers was taken from a study Woofter had published a decade earlier about a South Carolina sea island. ${ }^{19}$ In 1935, southern black sharecroppers on direct relief received the lowest monthly payments of all groups under the FERA principle of "budgetary deficiency" - just $\$ 4$ per household - while the one-in-five white farm owners relying on work relief in the Great Lakes cut-over area received \$27 a month. Woofter and Winston skated over this with the comment that in 1933 payments had been even lower and stated, "The adequacy of relief grants was in large measure determined by the administrative policies in the various states and by the amount of funds available." ${ }^{20}$ They were both liberal white southerners, but they complied with the racist orthodoxy as to whose misery mattered most. Historian Eileen Boris attributes this relentless stress on the white family, not so much to the authors' bias, as to "a reform strategy to give poverty a white face" in view of the Democratic Party's dominance in the South and its disproportionate power in congressional committees and presidential elections. ${ }^{21}$

\footnotetext{
${ }^{19}$ Ibid., 84-85. Woofter, Black Yeomanry, 119-20.

${ }^{20}$ Woofter and Winston, Seven Lean Years, 154-55. Average monthly payment to sharecropper families in June 1935 was \$9. Charles P. Loomis et al., Standards of Living in the Great Lakes Cut-Over Area (Washington, D.C.: U.S. Department of Agriculture, 1938).

${ }^{21}$ Boris, "Ellen Black Winston," 245. On key questions about race and liberalism in the 1930s, see William B. Thomas, "Conservative Currents in Howard Washington Odum's Agenda for Social Reform in Southern Race Relations, 1930-1936," Phylon, 45 (2nd Qtr., 1984), 121-34. Woofter knew the urban liberals of the AAA and the younger New Dealers who strove for racial justice and tenants' rights, such as Clark Foreman and Virginia Foster Durr, but he did not associate with either group.
} 
Woofter and Winston saw the "drama of the depression" as a chance to give lasting assistance to poor people who were hammered by low farm prices, drought, and public assistance cutbacks in 1937 but would gain nothing from the Social Security Act or New Deal hours and wages regulations. The sorry story of rural insecurity was all too familiar: once-successful families were now marooned by single crop production and irreparable erosion, low incomes, minimal savings, precarious tenancy, mounting taxes, debts, and foreclosures. Communities of small farms and towns were finally "submerged" when markets shrank, credit evaporated, machines began to displace labor, and cash incomes from rural construction, mining, or logging vanished (just one-in-eight farm laborers found employment in 1935 that did not derive from a government program). ${ }^{22}$

Tenants, especially young sharecroppers raising cotton or tobacco, were so trapped by debt and short leases that even a good yield might make little difference. Americans might not like the term, "peasant," Woofter and Winston observed, but it aptly described many citizens. They calculated that the incomes of five million farm families were below minimum urban subsistence levels and three million lived in complete poverty. Farm owners were not immune: the margins between success and failure were so narrow that half the 500,000 farm families on the FERA's emergency relief rolls in 1935 were owners facing heavy debts, drought, or ill-health. Rural youth transience, inadequate schooling and training, poor health, diets, and sanitation led Woofter and Winston to warn that "the depression will leave a lasting imprint on the next generation," unless the wealthy contributed more. ${ }^{23}$ The most "chronically underprivileged" families were found where the boll weevil struck cotton growers after 1910 and in the "Appalachian-Ozark, Lake States Cut-Over, Spring Wheat, and Winter Wheat" regions. Texas and Oklahoma also suffered high transport

\footnotetext{
${ }^{22}$ Woofter and Winston, Seven Lean Years, 5-44.

${ }^{23}$ Ibid., 45-87.
} 
costs and droughts in 1934 and 1936, and southern mountain regions from West Virginia to Arkansas battled eroded hillsides, deforestation, poor roads, and low literacy. Woofter and Winston concluded that, despite the recent efforts of the FERA Rehabilitation Program, the Resettlement Administration, the Soil Conservation Service, the Red Cross, and the Reconstruction Finance Corporation, millions of farm families faced a permanent dependence on relief. ${ }^{24}$

They therefore appealed for long-term policies to prevent distress They proposed large-scale flexible rehabilitation loans, supported by FSA land-use and home economics experts, and permanent public works programs to resettle all "relief farmers [in a] ... regionally balanced agriculture.” Acreage control, they argued, could cut commercial production as part of long-range planning, but not as a quick fix. Surplus food should be distributed cheaply or free, as in Sweden, "especially when the poorer classes are rearing the future population," while cooperatives would prevent deflationary surpluses and spread income equitably. They also called for a "population policy" to encourage "heavy migration" away from farms in drought-hit and cotton regions and envisaged an ideal mixture of farming, decentralized industry, and housebuilding to create employment. Finally, an attractive credit system, appropriate education, and new public health services would transform rural life..$^{25}$

They called on Congress to pay for this vision by using "the broader tax base of the whole nation." States with the biggest rural problems could never afford the required investment; their low tax returns meant they struggled just to match federal spending on unemployables, the aged, and children under the Social Security program. Woofter and Winston declared: "It is self-evident that if national standards of security and public welfare

\footnotetext{
24 Ibid., 89-147.

${ }^{25}$ Ibid., 148-73. On farm cooperatives, see Ellis Cowling, Co-operatives in America: Their Past, Present and Future (New York: Coward-McCann, 1938).
} 
are to continue to advance, increasing participation of the national government in equalizing state finances is necessary." Only then, would a massive enlargement of essential services create jobs and give rural America the same standards as the cities:

If a reasonable amount of foresight is exercised, American agriculture can be prevented from declining to the point where American farmers are forced to a peasant standard of living. However, if with the return of normal prosperity the rural sore spots are forgotten, they may be counted upon to pile up a staggering relief bill again whenever the national economy is thrown out seriously out of balance. ${ }^{26}$

The first New Deal had tried to maintain industrial workers' incomes and the demand for agricultural output, in the hope that farm families' purchasing power would alleviate the depression. The policy had failed, and relieving rural distress now offered limited gains: "A long-range plan of attack not subject to emergency psychology should be the goal.” Basically, the farmer's problems predated the slump - and the government needed to rehabilitate the victims of "the pioneering and the exploitative" stages of American agriculture. Woofter and Winston rounded off with a unifying New Deal flourish: "[T]he future welfare of America is at stake, and inextricably bound up with the welfare of rural areas. ... The nation cannot be permanently prosperous unless it rests on the solid foundation of a prospering rural population." 27

Perhaps Seven Lean Years is best understood as an expression of what socio-historian Jess Gilbert has referred to as the "Intended New Deal." Certainly, in 1938, a new momentum was needed if radical interagency collaboration was to help the rural

\footnotetext{
${ }^{26}$ Woofter and Winston, Seven Lean Years, 174-76.

27 Ibid., 149, 151, 176. See also Carle C. Zimmerman, review of Seven Lean Years, in American Journal of Sociology, 45 (Nov. 1939), 496-97. Popular treatments of federal rural research included Howard R. Tolley, The Farmer Citizen at War (New York: Macmillan, 1943), on New Deal planners' preparations for the coming war, and Arthur Raper, Tenants of the Almighty (New York: Macmillan, 1944), partly devoted to the DFPRL's landuse planning programs, as they operated in Greene County, Ga.
} 
disadvantaged. The United Farm Program and the Rural Life Trends Project sparked some interest in Congress in the work of the BAE and the Farm Security Administration (FSA), while Woofter and Winston were attempting what Gilbert calls an agrarian dialogue "between expert and citizen," but by now the energy of the New Deal was drained. ${ }^{28}$

In July 1939, amid a broad government reorganization, Woofter moved to the FSA, becoming chief economist and adviser to its administrator, Will Alexander, formerly head of the Resettlement Administration. During the 1920s, Woofter was one of Alexander's closest colleagues in the Commission on Interracial Cooperation in Atlanta and his FSA appointment was typical of Alexander's personal approach to filling senior positions. (A year later, in July 1940, Alexander departed for the National Defense Commission and the Rosenwald Fund, and was succeeded by C. B. Baldwin, an equally liberal Wallace associate. $)^{29}$ Woofter appeared with Alexander before the civil liberties subcommittee of the Senate Committee on Education and Labor, arguing for proper rehabilitation for farm families to limit wasteful migration, and seeking new tenancy reforms and access to public works for all rural Americans. ${ }^{30}$ He began work on a celebration of a decade of rural rehabilitation, but the FSA - described by historian Otis L. Graham, Jr., as "an odd combination of the anachronistic and the visionary" - was already faltering. Under Alexander and Baldwin, it remained an enclave of New Deal humanitarianism toward small farmers, including African Americans, but its resources lagged behind its practical democratic ambitions and its ability to aid tenants was

\footnotetext{
${ }^{28}$ Gilbert, Planning Democracy, 47, Part II. Congressional opinion was wary of land-use interventions, especially when farm policy and race intersected. Larson and Zimmerman, Sociology in Government, 51-55, 224-44. See also, Leo J. Zuber, review of Seven Lean Years, in Tennessee Planner, 1 (Jan.-Feb. 1940), 19-22. ${ }^{29}$ Personnel File, Thomas Jackson Woofter, Jr. (d.o.b. 6/18/93), Civilian Personnel Records, National Personnel Records Center (NPRC), St. Louis, Mo. Wilma Dykeman and James Stokely, Seeds of Southern Change: The Life of Will Alexander (New York: Norton, 1962), 224-50.

${ }^{30}$ New York Times, May 24, 1940, p.21. Senate Committee on Education and Labor, $76^{\text {th }}$ Congress, Violations of Free Speech and Rights of Labor, May 23, 1940, p.669-709. Congressional criticism contributed to the resignations of both Alexander and Baldwin. The FSA was replaced by the Farmers Home Administration in 1946. Baldwin, Poverty and Politics, 325-402. On FSA, see also Charles Kenneth Roberts, The Farm Security Administration and Rural Rehabilitation in the South (Knoxville: University of Tennessee Press, 2015); Larson and Zimmerman, Sociology in Government, 202-19; Kirkendall, Social Scientists and Farm Politics, 129-32.
} 
limited. Undaunted, and despite inherent financial and jurisdictional obstacles, and growing antagonism toward the FSA in Congress, Woofter called again for a policy of reducing the surplus farm population and taking sub-marginal farmland out of cultivation to combat malnutrition and disease. ${ }^{31}$ These things were delivered, to a degree, less by the New Deal, than by American entry into World War II.

In December 1940, Woofter resigned from the FSA to become research director of the new U.S. Federal Security Agency (USFSA). This agency, which became the Department of Health, Education, and Welfare in 1953, played a crucial role in policy transitions from New Deal to wartime, and from war to peacetime. It worked closely with the states and was the core vehicle for planning and delivering social security and public services during the 1940s. As one of its most senior appointees, Woofter advised the USFSA administrator, former Indiana governor Paul V. McNutt. He also directed a swathe of social science research across sixteen bureaus, including the Social Security Board, Office of Education, the Civilian Conservation Corps, National Youth Administration, the Children's Bureau, Food and Drug Administration, and the U.S. Public Health Service. His own research generated advanced methods for projecting demographic shifts and social security budget requirements. ${ }^{32}$

\footnotetext{
31 T. J. Woofter, Jr., and A. E. Fisher, The Plantation South Today (Washington, D.C.: U.S. Government Printing Office, 1940). Bradford [PA] Evening Star, June 25, 1940, p.6; New York Age, Nov. 9, 1940. p.11. Larson and Zimmerman, Sociology in Government, 203-204, 221. Roger Biles, A New Deal for the American People (DeKalb: Northern Illinois University Press, 1991), 67-68, 75. Otis L. Graham, Jr., Toward a Planned Society: From Roosevelt to Nixon (New York: Oxford University Press, 1976), 44-45. Woofter advised southern reform spokesman UNC President Frank Porter Graham before his testimony to the Senate's Special Committee to Investigate Unemployment and Relief in March 1938 and advised the Swedish sociologist, Gunnar Myrdal on southern race relations for An American Dilemma (1944). James F. Byrnes to Graham, Feb. 23, 1938; Ray E. Wakeley to Graham, March 2, 1938, folder 705, Frank Porter Graham Papers, Subseries 1.1, 1938, SHC, UNC. Progress reports, April 29, June 17, July 1, July 15, 1939, in "Weekly Progress Reports" folder, box 19, RG 69, NA. Gunnar Myrdal, An American Dilemma: The Negro Problem an American Democracy (New York: Harper, 1944), 1337.

${ }^{32}$ Woofter personnel file, NPRC. "Dr Woofter Research Director Federal Security Agency," Population Index, 7 (Jan. 1941), 13. "USFSA" is used here to avoid confusion with the Farm Security Administration (FSA). The bureau heads were all political appointees.
} 
In a critical evaluation of the USFSA, Mariano-Florentino Cuellar notes that its wartime remit also included "civil defense preparedness, supplying employees to war-related industries, facilitating the relocation of Japanese-Americans, antiprostitution enforcement, and biological weapons research." This controversial centralization of executive power included domestic regulatory and national defense functions that would continue after the war, leading USFSA officials to assert "the contribution made by research and statistics to national security." 33 In 1941-42, after McNutt assumed chairmanship of the War Manpower Commission, Woofter provided data and analysis for the Selective Service System. ${ }^{34} \mathrm{He}$ also addressed the National Conference of Social Work on pressures caused by sudden migration of workers to towns with defense plants and he appeared repeatedly before congressional committees to explain the chaos caused in several states by people with no supporting documents rushing for birth certificates after the 1941 War Act barred companies with government contracts from hiring aliens. ${ }^{35}$

In 1942-43, the government launched a series of planning activities for the post-war period, led by the Board of Economic Warfare, the National Resources Planning Board (NRPB), and the Federal Reserve. Woofter headed the USFSA's response through a program planning committee tasked with expanding social security, education, and health services. Promising to work through state and local agencies, he called for "getting planning down as

\footnotetext{
33 Mariano-Florentino Cuellar, "'Securing" the Nation: Law, Politics, and Organization at the Federal Security Agency, 1939-1953," University of Chicago Law Review, 76 (Spring 2009), 587-718. Louis Levine to Jack Woofter, Nov. 9, 1948, file 025, box 55, RG 235, Records of the Federal Security Agency, in Records of the Department of Health, Education, and Welfare, NA. In 1938, FDR proposed a Department of Public Welfare, but Congress objected; hence, the creation of the Federal Security Agency under the Reorganization Act of 1939. Richard Polenberg, Reorganizing Roosevelt's Government: The Controversy over Executive Reorganization, 1936-1939 (Cambridge, MA: Harvard University Press, 1966), 146-62. Biological weapons research was undertaken by the USFSA's secret bureau, War Research Services.

34 Lewis Hershey to T. J. Woofter, March 6, 1946, file 200.1, box 166, RG 235, NA.

${ }^{35}$ T. J. Woofter, Jr., Community Problems in Defense Areas (Chicago: American Public Welfare Association, 1941). House Committee on Census, $77^{\text {th }}$ Congress, Authorizing the Director of the Census to Issue Birth Certificates, June 10, 1942, p.65-73. House Committee on Immigration and Naturalization, $77^{\text {th }}$ Congress, Documentary Evidence of Citizenship, Feb. 11, 12, 17, 1942, p.27-30. Senate Committee on Commerce, $78^{\text {th }}$ Congress, Establishing a Bureau of Vital Records in the U.S. Public Health Service, Jan. 13, 1944, p.24-26.
} 
close to Main Street as you can get it." He also represented the agency on the NRPB's special Committee on Long-Range Work and Relief Policies, with New Deal veterans Will Alexander, Katharine F. Lenroot of the Children's Bureau, and Corrington C. Gill of the Office of Civil Defense. Their 550-page "social revolution" report, "Security, Work, and Relief Polices," was sent to the White House in December 1941 (a year before publication of Sir William Beveridge's plan for post-war Britain, Social Insurance and Allied Services), but Roosevelt delayed providing it to Congress until March 1943, when its Beveridge-ish "cradle to the grave" welfare proposals were promptly attacked as "socialistic." (The 1943 and 1945 Wagner-Murray-Dingell bills, inspired by this NRPB report, were blocked by the American Medical Association.) The report was followed in July 1943 by the NRPB's demobilization proposals, prepared by the Conference on Post-War Readjustment of Civilian and Military Personnel, on which Woofter again represented the USFSA. The demobilization report, one of the last things the board produced before it was abolished by Congress, was attacked by the Republican Party as "a bold bid for the vote of our soldiers and sailors." Nevertheless, NRPB analyses contributed to the design and passage of the Servicemen's Readjustment Act (G.I. Bill) in $1944 .{ }^{36}$

\footnotetext{
${ }^{36}$ Security, Work, and Relief Policies (Washington, D.C.: U.S. Government Printing Office, 1942). Berkshire Eagle [Pittsfield, MA], Oct. 8, 1942, p.5; Chicago Tribune, Dec. 11, 1942, p.2; New York Times, March 11, 1943, p.1, 13; Pittsburgh Press, March 11, 1943, p.9; Oakland Tribune, March 11, 1943, p.16; New York Times, July 31, 1943, p.1. Cincinnati Enquirer, March 14, 1943, p.5. Arthur J. Altmeyer, The Formative Years of Social Security (Madison: University of Wisconsin Press, 1966), 143-51. W. H. Beveridge, Social Insurance and Allied Services (London: HMSO, 1942). See also Martha Derthick, Policymaking for Social Security (Washington, D.C.: Brookings Institution, 1979). On NRPB, see Charles E. Merriam, "The National Resources Planning Board: A Chapter in American Planning Experience," American Political Science Review, 38 (Dec. 1944), 1075-88. On the contrasts in social sciences growth in the USA and Britain, and the differing relationships between academe and public policy, see Martin Bulmer, "National Contexts for the Development of Social-Policy Research: British and American Research on Poverty and Social Welfare Compared," in Peter Wagner et al., eds., Social Sciences and Modern States: National Experiences and Theoretical Crossroads (Cambridge: Cambridge University Press, 1991), 148-67; Björn Wittrock and Peter Wagner, "Social Science and the Building of the Early Welfare State: Toward a Comparison of Statist and Non-Statist Western Societies," in Dietrich Rueschemeyer and Theda Skocpol, eds., States, Social Knowledge, and the Origins of Modern Social Policies (Princeton: Princeton University Press, 1996), 90-113; Libby Schweber, "Progressive Reformers, Unemployment, and the Transformation of Social Inquiry in Britain and the United States, 1880s-1920s," ibid., 163-200.
} 
One of Woofter's main wartime contributions was nailing down the post-war costs of amendments made in 1939 to the original Social Security Act (although he did not suggest how those costs might be met or contained). As Wilbur J. Cohen, one of those responsible for the changes, put it, they "transformed it from just an old-age insurance program to an oldage and survivors' insurance program." ${ }^{37}$ In response to new provisions covering workers' widows and dependants, the Social Security Board tried to predict future survivors' benefits and maintenance budgets, while allowing for racial and regional income disparities, variable family composition, and post-war disability rates. ${ }^{38}$ Woofter used North Carolina as a testbed for the effects of this expansion of post-war social security provision. He also consulted with the leading African American sociologist, E. Franklin Frazier of Howard University, on black family income levels and exchanged detailed correspondence with prominent American demographers and actuaries Frank Lorimer, P. K. Whelpton, Louis I. Dublin, and Alfred J. Lotka, concerning methods for estimating the number of paternal orphans over five-yearly intervals - “a problem of very practical significance.” As summarized in Hugh Wolfenden's Population Statistics and Their Compilation, Woofter's calculations “were made by taking the number of births by age of father in each of the preceding 18 years, applying the death rates of fathers by age to determine the number of deaths among fathers, and using survival rates of children to compute the number of orphans surviving to the specified year." 39

\footnotetext{
${ }^{37}$ Katie Loucheim, ed., The Making of the New Deal: The Insiders Speak (Cambridge, MA: Harvard University Press, 1983), 157-58. Although federal social security was widened, more was paid out by the states' worker compensation schemes and veterans' programs. Edward Berkowitz, "Social Welfare and the American State," in Donald T. Critchlow and Ellis W. Hawley, eds., Federal Social Policy: The Historical Dimension (University Park: Pennsylvania State University Press, 1988), 172-73.

38 T. J. Woofter, Jr., "Preliminary Population Estimates Based on Ration Book Applications," Journal of the American Statistical Association, 37 (Dec. 1942), 437-40; T. J. Woofter, Jr., "A Method of Analysis of Family Composition and Income," Journal of the American Statistical Association, 39 (Dec. 1944), 488-96; T. J. Woofter, "Size of Family in Relation to Family Income and Age of Family Head," American Sociological Review, 9 (Dec. 1944), 678-84; T. J. Woofter, "Southern Children and Family Security," Social Forces, 23 (March 1945), 366-75, and reprinted in Howard W. Odum and Katharine Jocher, eds., In Search of the Regional Balance of America (Chapel Hill: University of North Carolina, 1945), 124-33.

39 Hugh H. Wolfenden, Population Statistics and Their Compilation (Chicago: University of Chicago Press, 1954), 225. Woofter to Gordon Blackwell, Sept. 25, 1945, file 052, box 130, RG 235, NA. Woofter to Martin Marimont, Jan. 6, 1945, ibid; Woofter to A. J. Lotka, June 14, 1945, ibid (this letter was 3,000 words long).
} 
Woofter, who began work on population statistics at UNC, saw this as the best way round the problem of predicting future patterns when the only firm yardstick was the decennial census. $^{40}$

Throughout the New Deal he had commented on demographic issues with increasing urgency and authority, and was referred to in the press as "the WPA's population expert." Hopkins approved Woofter's participation in the 1937 International Congress on Population Problems in Paris, where his presentation emphasized "the human elements that press for attention on the part of those guiding the nation's destiny." He complained that the USA lacked a "clear-cut policy [for] population planning" and urged "further research, exact and detailed knowledge" concerning annual increases in young job seekers, low urban birth rates, migration back to the poorest land, and the projected increase in old people from 6.6 million in 1930 to 14.2 million by $1960 .{ }^{42}$ He told a joint meeting of the Population Association of America (PAA) and the American Sociological Society in 1939 that, although employment

\footnotetext{
Woofter to Franklin Frazier, April 5, 1946, ibid. Howard University was administered by the USFSA. Recent research notes the obstacles to gaining certain kinds of work in the South for African Americans in the 1940s, but suggests racial wage differentials, themselves, were not large. See Celeste K. Carruthers and Marianne $\mathrm{H}$. Wanamaker, "Separate and Unequal in the Labor Market: Human Capital and the Jim Crow Wage Gap," Working Paper 21947 (National Bureau of Economic Research, Jan. 2016), 51pp. T. J. Woofter, "Children and Family Income," Social Security Bulletin, 8 (Jan. 1945), 1-6; T. J. Woofter, "Children and Family Security," Social Security Bulletin, 8 (March 1945), 5-10; T. J. Woofter, "Probabilities of Death in Closed Population Groups, Illustrated by Probabilities of Death of White Fathers after Birth of Children," Human Biology, 18 (Sept. 1946), 158-70. See also, Frank W. Notestein, "Demography in the United States: A Partial Account of the Development of the Field," Population and Development Review, 8 (Dec. 1982), 651-87. Dublin and Lotka worked for Metropolitan Life insurance company.

${ }^{40}$ T. J. Woofter, Jr., "Interpolation for Populations Whose Rate of Increase is Declining," Journal of the American Statistical Association, 27 (June 1932), 180-82.

${ }^{41}$ Dunkirk [NY] Evening Observer, May 16, 1939, p.13. See, for example, T. J. Woofter, Jr., "What is the Negro Rate of Increase?" Journal of the American Statistical Association, 26 (Dec. 1931), 461-62. T. J. Woofter, Jr., "Southern Population and Social Planning," Social Forces, 14 (Oct. 1935), 609-18. T. J. Woofter, Jr., "The Natural Increase of the Rural Non-Farm Population," Milbank Quarterly, 13 (Dec. 1935), 311-19. T. J. Woofter, Jr., "Replacement Rates in the Productive Ages," Milbank Quarterly, 15 (Dec. 1937), 438-54. T. J. Woofter, Jr., "The Future Working Population," Rural Sociology, 4 (Sept. 1939), 275-82.

${ }^{42}$ Gazette and Daily [York, PA], Aug. 9, 1937, p.3. Intermittent conferences followed the 1927 World Population Conference in Geneva, chaired by Margaret Sanger under League of Nations auspices (the culmination of six international birth control conferences). At the Paris Conference, where population collapse due to falling fertility was predicted, proposed German and Italian participation led to boycotts. Schoen, Coercion and Choice, 198. New York Times, July 30, 1937, p.4. Woofter to Hopkins, June 25, 1937, folder 27, box 54, Harry L. Hopkins Papers, Special Collections Division, Georgetown University, Washington, D.C.
} 
had reached 1930 levels (i.e., 35 million), unemployment had doubled to 11 million because a million young people reached working age annually. This required the USA to create 19.5 million jobs over the next two decades. He saw little point in trying to limit population growth through birth control and immigration restriction, because falling birth rates would produce an eventual rise in the average age of the population. Instead, in statements that echoed his work on agriculture, he pointed to demographic projections showing the need for a "long-range public employment program [and a] different distribution of income - an increase in the purchasing power of the lower third of the population." 43 He repeated these radical warnings in 1940, when he became PAA president and joined other leading demographers, such as Whelpton, Lorimer, William F. Ogburn, and Rupert B. Vance, in advising individual state planning boards and giving radio talks for the PAA. Although Woofter collaborated with mid-century American social demographers who advanced theories concerning the cause and effects of population change, he did not share the enthusiasm of some of them for social eugenics, and as PAA president he helped distance the association from its eugenicist, birth control, and nativist origins. ${ }^{44}$

In the aftermath of depression and war, no government could enhance the welfare system and maintain national security without effective statistical forecasting concerning manpower and fertility. In 1944, Woofter and the Census Bureau noted continuing concerns that American birth rates, especially in cities, might not replace the existing population and

\footnotetext{
${ }^{43}$ Dunkirk Evening Observer, May 16, 1939, p.13; Harrisburg [PA] Evening News, Dec. 27, 1939, p.1; Gazette and Daily), Dec. 29, 1937, p.6. Woofter advised the Children's Bureau's White House Conference on Children in a Democracy in January 1940. See Proceedings... [Bureau Publication No. 266] (Washington, D.C.: U.S. Government Printing Office, 1940).

${ }^{44}$ Binghamton Press and Sun-Bulletin, March 13, 1940, p.25. Newport News Daily Press, April 16, 1940, p.12. Edmund Ramsden, "Social Demography and Eugenics in the Interwar United States," Population and Development Review, 29 (Dec. 2003), 547-93. “Association Cooperates in Radio Series," Population Index, 6 (Oct. 1940), 255-56. Woofter also sat on the Rural Sociological Society executive with Carl C. Taylor of USDA and Dwight Sanderson of Cornell University, and joined Taylor as an incorporator of the American Sociological Society (later, Association) in 1943. Lawrence J. Rhoades, A History of the American Sociological Association, 1905-1980 (1981) at http://www.asanet.org
} 
labor force, even if the already-evident baby boom persisted. This was part of an old debate about the optimum size of the American population, in which long-term stability was increasingly seen as the best outcome. ${ }^{45}$ During and after World War II, Woofter refined American reproductivity measurements, by focusing less on the number of births for any given year, and more on the fertility and mortality of a given cohort of women. By comparing reproductivity of women aged 15 to 44 in 1944 with female mortality rates since 1915 , he arrived at a "generation net reproductive rate." This differed from conventional methods and showed the reproduction rates between 1923 and 1938 of American women born between 1895 and 1910 falling less fast than other studies; Woofter's approach would be taken forward by Whelpton. ${ }^{46}$

At the end of the 1940s, Woofter commented on the number of demographers, including himself, who had wrongly predicted that fertility and populations would continue to decline in industrial societies. He now attributed falling birth rates in the 1930s and rising rates in the 1940s to economic fluctuations: during and after the war higher incomes made having children more affordable and the effect of better living standards was to slash rates of sterility, infant mortality, and prenatal death; for example, the death rates of five-year-old

\footnotetext{
${ }^{45}$ Medford [OR] Mail Tribune, June 22, 1944, p.8. Derek S. Hoff, The State and the Stork: The Population Debate and Policy Making in US History (Chicago: University of Chicago Press, 2012), 11-12. On the baby boom, see Dan Bouk, "Generation Crisis: How Population Research Defined the Baby Boomers," Modern American History, 1 (Nov. 2018), 321-42. Frederick E. Hosen, The Great Depression and the New Deal (Jefferson, NC: McFarland, 1992), 250-55.

${ }^{46}$ Henry S. Shyrock, Jacob S. Siegel, et al., The Methods and Materials of Demography, Volume 2 (Washington, D.C.: U.S. Government Printing Office, 1973), 537-39. T. J. Woofter, "Completed Generation Reproduction Rates," Human Biology, 19 (Sept. 1947), 133-53; T. J. Woofter, "The Relation of the Net Reproduction Rate to Other Fertility Measures," Journal of the American Statistical Association, 44 (Dec. 1949), 501-517. Jean van der Tak, Arthur Campbell interview, Feb. 16, 1988, Demographic Destinies, 1/2 (2005), 285. See also, P. K. Whelpton, "Cohort Analysis of Fertility," American Sociological Review, 14 (Dec. 1949), 735-49. Woofter's cohort studies led to disagreements with Lotka, one of the founders of mathematical demography. Louis Henry, "L'assemblée de l'Union internationale pour l'étude scientifique de la population," Population, 4 (Oct.Dec. 1949), 749-51. The insurance industry, for which Lotka worked, was opposed to the accumulation of large social security funds.
} 
girls and middle-aged women were half those of $1900 .{ }^{47}$ In other words, prospects for rural and urban family formation and stability were transformed between 1940 and 1950 .

Woofter proved extraordinarily useful and adaptable in employing his demographic expertise to assist planners and decisionmakers; he headed up groups on new policy matters and represented the federal security administrator on interdepartmental bodies, such as the Presidential Research Board. He also advised Commerce Secretary Henry A. Wallace on transferring the Vital Statistics Division from the Census to the U.S. Public Health Service, supplied welfare data to Acting Secretary of State Dean Acheson for debates in the Economic and Social Council of the United Nations, helped the Justice Department's review of immigration policy, and regularly briefed members of Congress. He also tracked international developments, comparing notes on family composition and income with Louis Moss, director of the British Wartime Social Survey which was co-opted by the Ministry of Information, and monitored South American attempts to boost post-war immigration. ${ }^{48}$ In 1946, another major federal reorganization saw the USFSA expanded and the start of a complete re-examination of government research needs. For two years, Woofter led a comprehensive review that detailed 122 ongoing research projects, 52 planned projects, and 55 evaluations across the four USFSA sub-agencies - Public Health Service, Social Security Administration, Office of Education, and Office of Special Services - showing the new reliance by the federal and state governments on trained social scientists for the appraisal of Fair Deal policy decisions affecting every citizen, and the beginnings of a data revolution unthinkable during the Coolidge era just two decades earlier. ${ }^{49}$

\footnotetext{
${ }^{47}$ T. J. Woofter, "Factors Sustaining the Birth Rate," American Sociological Review, 14 (June 1949), 357-66. New York Times, July 17, 1949, p.E10.

48 T. J. Woofter to Albert J. Engel, March 22, 1945, file 052, box 130, RG 235, NA; Watson Miller to Dean Acheson, May 21, 1946, file 241.3, box 197, ibid.; H. A. Wallace to Miller, file 320, box 244, ibid.; Woofter to L. Moss, April 3, 1945, file 520, box 83, ibid; Oscar Ewing to Miller, March 25, 1948, file 201, box 178, ibid. T. J. Woofter, "Saving the Lives of Good Neighbors," American Sociological Review, 12 (Aug. 1947), 420-23.

${ }^{49}$ Woofter to Agency Research Committee, Dec. 31, 1947, file 025, box 55, RG 235.
} 
In the summer of 1949, President Truman signed the Central Intelligence Agency Act, giving the CIA more money and freedom, and reorganizing the agency in ways that enabled the poaching of specialists from across the federal government to improve gathering and analysis of data. ${ }^{50}$ In September 1949, having transformed research and project management in the Federal Security Agency, Jack Woofter moved from work dominated by public welfare to national security. He joined the CIA as chief of the Labor and Manpower (later, Population and Labor) Branch of the Economic Services Division in the Office of Research and Reports. He was hired for his skill as a research director, sociologist, and demographer, and especially his techniques for forecasting population and manpower trends, as intelligence chiefs looked for improved data on America's adversaries. ${ }^{51}$ The hiring of division and branch chiefs with academic credentials was not uncommon; hence, Woofter's recruitment for intelligence work, traceable through impersonal, declassified, and partially redacted CIA documents. ${ }^{52}$

After World War II, as Michael Desch shows in Cult of the Irrelevant, the armed services took note of social science research and during the Cold War most government departments used social scientists in organizational and strategic planning. Desch argues that

\footnotetext{
${ }^{50}$ Rhodri Jeffreys-Jones, The CIA and American Democracy, $3^{\text {rd }}$ ed. (New Haven: Yale University Press, 2003), 59-60.

${ }^{51}$ Federal Security Agency, Notification of Personnel Action re. T. J. Woofter, Sept. 12, 1949, Woofter personnel file, NPRC. At the USFSA, Woofter received consistent "Excellent" efficiency ratings for judgement, planning, liaison, presentation, and procedural skills. He was at the top of the civil service professional salary scale (P-8, \$10,330, under the 1948 Pay Act). Through the PAA, he collaborated with Social Security Board economist Eleanor Lansing Dulles and Swedish sociologist Alva Myrdal. Population Index, 5 (April 1939), 80.

52 Jeffreys-Jones, CIA and American Democracy, 8-9. Jeffreys-Jones noted the CIA's preference for recruiting outstanding senior staff using "the principle of the New Deal's brain trust." Woofter found himself working with several people he had encountered in the Roosevelt administration. The State Department's head of Population and Labor, William T. Ham, had worked with Woofter in the BAE and the Division of Farm Population and Rural Life, as did Waller Wynne, Jr., author of several Communist state population studies for the Census Bureau. Wynne had helped with research for Landlord and Tenant on the Cotton Plantation in 1936. A. Ross Eckler, deputy director of the Census, was a statistician in the FERA.
} 
at the same time many social scientists perceived a choice between "rigor and relevance," the implication being that universities were strongholds of "rigor," whereas academics who sought "relevance" opted for government work. ${ }^{53}$ Many of those who did important studies for the government during the war, such as the psychologist Rensis Likert and the sociologist Samuel Stouffer, returned to university-based research in 1946. As a civil servant, Woofter tried to exhibit both rigor and relevance, working on population and competitive manpower assessments for strategic defense purposes, whilst maintaining his association with scholars like Stouffer through the PAA and the American Statistical Association. He nevertheless became detached from some of the debates over population control that preoccupied internationalist American demographers such as Notestein and Lorimer (although their work on wartime Europe and "emerging nations" had Cold War relevance). ${ }^{54}$

In 1947, Congress enlarged budgets and research staffing for intelligence work through the National Security Act, giving the CIA analytical functions and a military-civilian leadership intended to reduce interdepartmental rivalry. ${ }^{55}$ Dissatisfaction and tensions surrounding demographic intelligence were clear: Deputy Director of Military Intelligence Gen. Walter E. Todd complained to CIA Director Adm. Roscoe H. Hillenkoetter about the "duplication, wasted effort and needless expense" associated with the "production and dissemination of sociological intelligence in the field of population and manpower studies by various government agencies." It would, he stated, be "most efficiently and economically produced under central direction," allowing for "standardization of methods of compiling and maintaining data” for the National Intelligence Survey. Naval Intelligence Director Adm.

\footnotetext{
${ }^{53}$ Michael C. Desch, Cult of the Irrelevant: The Waning Influence of Social Science on National Security (Princeton: Princeton University Press, 2019), 89, 96-101.

54 On growth of the international population movement, see Matthew Connolly, "Seeing Beyond the State: The Population Control Movement and the Problem of Sovereignty," Past and Present, 193 (Nov. 2006), 197233, and Emily Klancher Merchant, "A Digital History of Anglophone Demography and Global Population Control, 1915-1984," Population and Development Review, 43 (March 2017), 83-117.

55 Jeffreys-Jones, CIA and American Democracy, 39-41.
} 
Thomas B. Inglis agreed, calling for "production of population and manpower studies [to be] ...coordinated by the Central Intelligence Agency,... incorporated into the basic intelligence program," and evaluated by a new "central working unit." ${ }^{\text {"56 }}$ The Inter-Agency Committee on Population and Manpower Studies also insisted that an "adequate inventory of the human resources of foreign countries... [was] essential to both strategic and political operations," and that the USA's commitments required systematic intelligence relevant to the "war potential of strategic countries[,] foreign aid programs and growing world-wide concerns of American foreign policy." For much of the world, including China, even basic statistics were considered "seriously incomplete or defective." It was obvious that demographic intelligence was fragmented and weak, partly because different services were demanding different data: Army Intelligence (G-2) monitored strategically important foreign military manpower; the US Air Force's Target Analysis Division gathered "minute details," from "fugitive sources" if necessary, about industry and population centers; three analysts in the State Department's Division of International and Functional Intelligence monitored key occupations, education, ethnicity, vital statistics, and disease in selected countries; and the Census Bureau gathered publicly available foreign demographic data, despite doubts about the reliability of official information. ${ }^{57}$

Woofter chaired the new Advisory Committee on International Population Statistics, which in February 1952 became the Subcommittee on Population and Manpower of the

\footnotetext{
${ }^{56}$ Walter E. Todd to Director, Central Intelligence, Sept. 25, 1947, CIA-RDP79-01143A000400010023-3, General CIA Records, CIA Library (CL), https://www.cia.gov/library/readingroom/collection/general-cia-records. Thomas B. Inglis to Director, Central Intelligence, Oct. 31, 1947, CIA-RDP79 - 01143A000400010017-0, CL. 57 "Population and Manpower Studies: Present Facilities and Requirements of the Intelligence Agencies," [annex to memo to CIA director from Inter-Agency Committee on Population and Manpower Studies, Jan. 22, 1948] CIA-RDP79-01142A000400010010-7, CL. The Chinese population baffled demographers. See Emily R. Merchant, "Prediction and Control: Global Population, Population Science, and Population Politics in the Twentieth Century" (PhD diss., University of Michigan, 2015), 210. The CIA Office of Reports and Estimates distributed raw data from central and eastern European newspapers on repatriations, marriage, births and deaths, and employment by industry and sector. See "Information from Foreign Documents or Radio Broadcasts" [Czech press, May 31-July 9, 1949], Aug. 22, 1949, CIA-RDP80-00809A0006000241136-3, CL.
} 
CIA's influential Economic Intelligence Committee (EIC), an agenda-setting forum for numerous departments, agencies, and commissions. The fortnightly Population and Manpower meetings included sociologist Charles E. Hutchinson of the USAF's Human Factors Division, Russian-born demographer Eugene Kulischer of the Library of Congress, who advised the Air Force on European labor supply distribution, Conrad Taeuber of the Census Foreign Manpower Research Office, Oscar Weigert of the Labor Department's Division of Foreign Labor Conditions, and Theodor Lit, the Labor Department's Central and Eastern European specialist. State Department objections to the merging of its own liaison committee on Soviet and Eastern European manpower with the CIA's interdepartmental demographic committee were overruled. ${ }^{58}$

Woofter co-ordinated this disparate research capacity and attempted to provide the CIA and the Joint Chiefs with a coherent picture of population and manpower changes and projections for key regions of the world. Military strength was measured in terms of American ability to overcome the Soviet Union; and yet, the administration's policy objective was the reduction of conventional forces, making the demographic projections of the Subcommittee on Population and Manpower strategically and politically significant. Woofter's remit was “to examine continuously intelligence bearing upon foreign populations and manpower for the purpose of assisting in the elimination of gaps and deficiencies in such intelligence which may be detrimental for the security of the United States." His committee

\footnotetext{
${ }^{58}$ Asst. Dir., ORE, to Chief, COAPS [State], Dec. 2, 1949, CIA-RDP79-01143A000400010001-7, CL. EIC, Subcommittee on Population and Manpower, First Progress Report (April 10, 1952 - June 10, 1952), June 11, 1952, CIA-RDP82-00283R000200130002-0, CL. EIC, Subcommittee on Population and Manpower, Oct. 1, 1952, CIA-RDP92B01090R000200120002-4, CL. See Theodore Lit, Unions in Democratic and Soviet Germany: Contrasting Roles of Labor Organizations Under Free and Totalitarian Systems in Divided Postwar Germany (Washington, D.C.: U.S. Government Printing Office, 1953). Department of State Bulletin, 13 (Oct. 21, 1945), 640-41. Hutchinson later ran the Behavioral Sciences Division of USAF's Office of Scientific Research. Desch, Cult of the Irrelevant, 102, 110-12. Kulischer documented the Holocaust and wartime migration, after fleeing Vichy France in 1941. See Eugene M. Kulischer, Europe on the Move: War and Population Changes, 1917-1947 (New York: Columbia University Press, 1948), vi; Kulischer, "Russian Manpower," Foreign Affairs, 31 (Oct. 1952), 67-78.
} 
set about evaluating all existing intelligence analyses of manpower and labor in the Soviet Union and its satellites, and commissioned new research as necessary, such as Jacob Siegel's The Population of Hungary, so as to create standardized country information sets that could underpin the CIA's National Intelligence Survey. ${ }^{59}$

Military and economic security were paramount, but softer diplomatic and humanitarian impulses also played a part. The State Department's Office of Intelligence and Research sought foreign demographic data to support human rights policies and the work of health organizations combatting epidemics (its representative on Woofter's committee, Dudley Kirk, was an expert on health and population problems in the Near East, Asia, and Africa). In the summer of 1952, in the committee's first progress report, Woofter outlined a program of highly ambitious international studies requiring masses of data on friendly and unfriendly nations:

This would include subjects such as size, composition, distribution, changes, character, and movements of the population and labor force; employment and unemployment, wages, hours and economic conditions and social welfare of labor; conditions of work; relations between employees and government and management; organizations and policies of employers and employees; hiring and recruiting of labor; public health and education. ${ }^{60}$

\footnotetext{
${ }^{59}$ First Progress Report, June 11, 1952. Jacob S. Siegel, The Population of Hungary (Washington, D.C.: US Government Printing Office, 1958). In the same series, see also Paul F. Myers and Wayman Parker Maudlin, Population of the Federal Republic of Germany and West Berlin (1952); Waller Wynne, The Population of Czechoslovakia (1953); Maudlin and Donald S. Akers, The Population of Poland (1954); Myers and Arthur A. Campbell, The Population of Yugoslavia (1954); US Census Bureau, The Population of Mainland China, 1953 (1955); Wynne, The Population of Manchuria (1958); Samuel Baum and Jerry W. Combs, The Labor Force of the Soviet Zone of Germany and the Soviet Sector of Berlin (1959). Jean van der Tak, Jacob Siegel interview, June 21, 1988, Demographic Destinies, 1/3 (2005), 90. Jean van der Tak, Arthur Campbell interview, Feb. 16, 1988, ibid., 1/2 ((2005), 278-91. Campbell recalled (p.279), "I remember having made an age distribution for China around the time of their first census when they were not releasing very much information and you really had to make a lot of guesses about what their age distribution was."

${ }^{60}$ First Progress Report, June 11, 1952.
} 
His completed survey of all government research on the population and manpower of the Soviet bloc highlighted the "scarcity of personnel" and numerous gaps in essential information. The Labor Department and State Department wanted more information on living standards, labor law, workers' morale in Eastern Europe, forced labor in China, and short- and long-run population and manpower estimates; the USAF, as ever, wanted more intelligence on "strategic air target areas" - such as the residential zones of industrial, construction, and government workers. ${ }^{61}$

Southeast Asia became a looming concern in August 1954, when the Geneva Accords partitioned Vietnam after the First Indochina War. Woofter and the Population and Manpower Branch produced an Intelligence Memorandum on the region for the Joint Chiefs and their intelligence directorates, and the recently-formed National Security Agency. At the time, the US Navy was helping to relocate 300,000 Vietnamese people from the North to the southern zone in Operation "Passage to Freedom," part of the movement of one million civilians, in total, encouraged by intensive CIA propaganda. ${ }^{62}$ Working largely from French materials of varying currency, Woofter estimated the populations of every province and city in Indochina, showing 30 million people still under "French Control" and less than half that number under “Communist Control." He highlighted complex ethnic groupings and colonial legacies, including stark disparities in regional development and population density; for Vietnam, in particular, he calculated that $60 \%$ of the 7 million men of military age were

\footnotetext{
61 EIC, Subcommittee on Population and Manpower, Second Progress Report (July-Dec., 1952), Dec. 15, 1952, CIA-RDP82-00283R000200130001-1, CL. Third Progress Report, July 2, 1953, and Fourth Progress Report, Aug. 23, 1954, CIA-RDP82-00283R000200130004-8, CL. On USAF's capacity for targeting population centers, see Taiwoo Kim, "Limited War, Unlimited Targets: U.S. Air Force Bombing of North Korea during the Korean War, 1950-1953," Critical Asian Studies, 44:3 (Sept. 2012), 467-92.

${ }^{62}$ Ronald B. Frankum, Jr., suggests Operation “Passage to Freedom" paved the way to U.S. combat in Vietnam, having "established the moral obligation to ensure that those people's lives would improve under a democratic government, free from the threat of communism." See Frankum, Operation Passage to Freedom: The United States Navy in Vietnam, 1954-1955 (Lubbock: Texas Tech University Press, 2007), xx-xxi. Jonathan Nashel, Edward Lansdale's Cold War (Amherst: University of Massachusetts Press, 2005), 60-63.
} 
under Viet Minh rule. ${ }^{63}$ Thus, basic demographic and cultural information was accumulated by US intelligence and military strategists on Vietnam during the mid-1950s, but it fell far short of anything that would support planning for future intervention.

After 1955, the CIA could point to an increased number of expert staff producing intelligence on population and manpower across the federal government. The crossdepartmental Population and Manpower subcommittee was said to work well, "based on competence, good fellowship, and mutual respect," although its members continued to differ on optimal analytic methods and global priorities. ${ }^{64}$

The Eisenhower administration's New Look (NSC 162/2), formulated in October 1953 by the Joint Chiefs following the death of Stalin and a Korean truce, had declared that American "qualified manpower annually coming of military age is adequate to carry out our existing military plans," but this judgement relied heavily on accurate forecasts of foreign manpower and productivity. The government also committed itself to finding "feasible political, economic, propaganda and covert measures designed to create and exploit troublesome problems of the USSR,... and retard the growth of the military and economic potential of the Soviet bloc." 65

Cold War strategy was still hampered by "critical deficiencies" in the Census Bureau's data on Soviet industrial labor productivity and its provincial data on China and Southeast Asia. It took several years for Woofter's efforts to produce the sort of range, quality, and integration of demographic intelligence that could document Soviet

\footnotetext{
${ }^{63}$ Chief, Projects Control Staff, ORR, to Chief, Liaison Div., OCD, Sept. 2, 1954, CIARDP79T00935A000300030002-7, CL; CIA/RR IM-389, “Population and Manpower in Indochina," Sept. 1, 1954, CIA-RDP79T00935A0002000360001-3, CL.

${ }^{64}$ EIC Subcommittee on Population and Manpower to EIC Secretariat, Aug. 22, 1955, CIA-RDP8200283R000200130027-3, CL. EIC evaluation of Population and Manpower, Nov. 1, 1955, ibid. 65 John L. Gaddis, Strategies of Containment: A Critical Appraisal of American National Security during the Cold War, rev. ed. (New York: Oxford University Press, 2005), 125-96. E. Raymond Platig, "The 'New Look' Raises Old Problems," Review of Politics, 17 (Jan. 1955), 111-35. NSC 162/3, "Basic National Security Policy", Oct. 30, 1953, at https://fas.org/irp/offdocs/nsc-hst/nsc-162-2.pdf
} 
“troublesome problems." By 1958, his committee arrived at reliable indicators for productivity in Poland, Romania, Bulgaria, Hungary, Czechoslovakia, and "Soviet Germany," along with "a wide area of agreement on basic data and method." Post-war work on the Soviet Union had focused on defection and repatriation, civilian employment, the "New Lands Program," and forced labor, but the size of the population, itself, was regarded as an established fact. Major revisions were considered, therefore, after June 1956, when the USSR's new handbook, The National Economy of the USSR, gave a population figure of 200.2 million people - between 20 and 40 million fewer than most western calculations. If this was true, Woofter and his committee concluded, "It meant that the USSR had sustained much larger losses during and immediately after World War II than had been estimated." This would imply that the war's devastating effects on the birth rate and infant mortality had created "much smaller age cohorts, particularly in ages 10-15 years old." A Census Bureau specialist on the Soviet Union, Jim Brackett, later recalled, "The new data were received with shock and disbelief in our office, particularly by the emigres. ... The new data were potentially very valuable, and they had to be scrutinized carefully to determine their reliability." Brackett and his colleagues concluded that Soviet military and civilian war losses and depressed wartime birth rates caused a net population decline of 30 million. This, they realized, would mean labor shortages, with implications for the USSR's Five Year Plans and especially the Sixth and Seventh Five Year Plans (for 1956-60, and 1960-65), and suggested that "the estimates of, and Soviet policies on, forced labor, armed forces, and other non-reported categories of labor force were going to become more important than previously thought in the production of intelligence estimates of Soviet capabilities." (Regarding China, the Census Bureau and Library of Congress concentrated on urban population characteristics, 
which the CIA analysed and integrated with policy objectives in a series of studies on education, manpower, agriculture, and population control after 1956. ${ }^{66}$

Drawing on new Census projections of Soviet fertility and population up to 1975 and a re-assessment of age-sex distributions, Woofter issued a comparative Intelligence Memorandum, "Population Fertility in the USSR and the US." He noted entirely opposite trends in the two superpowers: Soviet fertility was shown dropping by 18-20\% after 1940 before stabilizing, whereas US fertility had risen between $37 \%$ and $55 \%$ and was continuing to increase. The US wartime baby boom and the "abnormally small number of war babies in the USSR" produced dramatically different labor force scenarios for the superpowers in the 1960s, in which the USSR would be required to shift farm workers into industry, increase productivity, direct school-leavers into key occupations, postpone retirement for elderly workers, and reduce numbers in the armed forces. The significant Soviet advantage over the USA in terms of men of military age (a gap of some 7 million in 1956) was expected to fall to just 3 million by $1975 .{ }^{67}$ These were all vital inferences for defense policymakers.

The clear value of demography to long-term security planning saw seventy government personnel engaged in "economic intelligence and related economic research" concerning foreign population and manpower studies by 1958; fifty of them worked on the Sino-Soviet bloc and all were in agencies represented on Woofter's committee. In a move

\footnotetext{
${ }^{66}$ EIC evaluation of Population and Manpower, Nov. 1, 1955, CIA-RDP82-00283R000200130027-3, CL. Annual Review of Activities...EIC Subcommittee on Population and Manpower, Aug. 8, 1956, CIA-RDP8200283R000200130026-4, CL. Annual Review of Activities..., EIC Subcommittee on Population and Manpower, Sept. 13, 1957, CIA-RDP82-00283R000200130025-5, CL. Previous estimates relied on work by demographer Frank Lorimer. See Lorimer, The Population of the Soviet Union: History and Prospects (Geneva: League of Nations, 1946). The USAF and the Air Research Division of the Library of Congress produced annual demographic estimates for China and the Soviet Union and began an urban and regional series of 152 studies and a "Target Data Inventory." Jean van der Tak, James Brackett interview, March 29, 1988, Demographic Destinies, 2 (2005), 79-80; Jacob Siegel interview, ibid., June 21, 1988, ibid, 1/3 (2005), 90.

${ }^{67}$ Chief, Projects Control Staff, ORR, to Asst. Director, Research and Reports, Jan. 8, 1957, CIARDP79T00935A000300030002-7, CL; CIA/RR IM-445, "Population Fertility in the USSR and the US, 1940-55," Jan. 21, 1957, CIA-RDP79T00935A0002000360001-3, CL. On challenges in estimating Soviet capabilities and spending, see W. T. Lee, "The Shift in Soviet National Priorities to Military Forces, 1958-85," Annals of the American Academy of Political and Social Science, 457 (Sept. 1981), 46-66. Lee worked for the CIA, 1951-64.
} 
consistent with Eisenhower's second term attempts at open communication with the Kremlin, the State Department proposed exchange visits by Russian and American demographers and census officials. Although such dialogue on population studies did not, in fact, commence until the late 1960s, it was not an outlandish suggestion in 1958; in that year, US experts on social security visited the USSR and hosted a Soviet delegation in return, and similar exchanges involving print and radio journalists, mining engineers, and agricultural experts took place. ${ }^{68}$ When Woofter's decade of secret population studies ended with his retirement in 1958, aged sixty-five, his CIA branch and his cross-departmental committee were coordinating demographic expertise in three areas vital to Eisenhower's foreign policy: war planning, propaganda, and economic competition.

Firstly, strategic air planning for a preferred "massive retaliation" through a second strike required robust data on the location, size, and concentrations of the civilian population and likely enemy losses. Less favored strategies also relied on demographic data: for example, according to advice given to presidential military adviser Gen. Maxwell Taylor by his Air Force staff assistant in 1961, another Berlin crisis might require a low-altitude first strike against military targets, "to eliminate Soviet intercontinental threat and ... minimize damage to Soviet population, industry and governmental authority.... This kind of attack, employing air burst 1MT weapons, might result in Soviet casualties of less than 1 million and probably not more than 500,000."69 Such assumptions, reliable or otherwise, were impossible without the work of government demographers.

\footnotetext{
68 EIC Minutes, July 6, 1958, extract, CIA-RDP82-00283R000200130024-6, CL. Annual Report... on Population and Manpower for Fiscal Year 1958, Aug.2, 1958, CIA-RDP82-000283R000200130022-8, CL. The next Soviet census date was January 1959; the US Census was in April 1960. Frederick Chase Barghoorn, The Soviet Cultural Offensive: The Role of Cultural Diplomacy in Soviet Foreign Policy (Princeton: Princeton University Press, 1960), 268-335. Yale Richmond, Cultural Exchange and the Cold War: Raising the Iron Curtain (University Park: Penn State University Press, 2003), 70-71. Elmer Plischke, "Eisenhower's "Correspondence Diplomacy" with the Kremlin - Case Study in Summit Diplomatics," Journal of Politics, 30 (Feb. 1968), 137-59.

${ }^{69}$ Maj. William Y. Smith to Gen. Maxwell Taylor, Sept. 7, 1961, Kennedy Library, at National Security Archive, https://nsarchive2.gwu.edu/NSAEBB/NSAEBB56/
} 
Secondly, there was thought to be immense propaganda value in showing the gulf between occupational freedoms, labor productivity, and living standards in the USA and in the USSR. ${ }^{70}$ Thirdly, it was essential for American planning purposes to gather intelligence on the Soviet Union's capacity to commit sufficient manpower to its infrastructure and output objectives, and sustain its military presence in the communist bloc. This forecasting capacity grew out of Woofter's work in laying the foundations for Census Bureau and CIA studies of Soviet and other foreign populations for the duration of the Cold War. Annually revised demographic studies, such as "Population of the Communist Countries, Selected Years, 19381980," fed into the National Intelligence Survey and were adapted for the CIA's "Population Wall Chart," which itself evolved into the National Basic Intelligence Factbook. (This compilation was declassified in 1971 and renamed World Factbook in 1981.) By the mid1960s, standardized demographic intelligence was embedded in national security conversations, so that the role Woofter initially assumed in the CIA, adjudicating between agencies determined to protect their own data and methods, was no longer required. The Subcommittee on Population and Manpower was wound up by the EIC in 1966 and its functions given to the Subcommittee on General Economic Analysis, but Woofter's work during the 1950s left a legacy of coherence and consistency in a vital area of classified government research. ${ }^{71}$

IV

\footnotetext{
${ }^{70}$ Nicholas J. Cull, The Cold War and the United States Information Agency: American Propaganda and Public Diplomacy, 1945-1989 (New York: Cambridge University Press, 2008), 104-119. Scott Lucas, Freedom's War: The US Crusade Against the Soviet Union, 1945-56 (Manchester: Manchester University Press, 1999), $202-203$. ${ }^{71}$ See, for example, James W. Brackett, Projections of the Population of the USSR, by Age and Sex: 1964-1965 (Washington, D.C.: U.S. Government Printing Office, 1964). Annual Report... on Population and Manpower for Fiscal Year 1958, June 10, 1958, CIA-RDP82-00283R000200130017-4, CL. Recommendation for Abolition of Subcommittee on Population and Manpower, March 22, 1966, CIA-RDP82-00283R000200210082-3, CL.
} 
Jack Woofter's first job after graduate school in 1913 was three years of fieldwork for a study of southern black education, paid for by a New York philanthropic fund and published by the U.S. Bureau of Education. Like other reports on social conditions in the Progressive era, it was welcomed by a federal administration that was happy to benefit from the resources and expertise of reform-minded citizens, but not inclined to investigate regional racial conditions for itself, let alone intervene. ${ }^{72}$ Twenty years on, when the US government was more fully engaged with social science research during the Great Depression, it relied on directors of research like Woofter. These were scholars who willingly left academic life for work that was directly relevant to urgent social problems and reforms, despite the limited recognition and career progression on offer and the susceptibility of programs to changes in policy. Woofter's own career was to differ from that of many academics who worked in Washington in the 1930s and 1940s, in that his skills were constantly in demand and were highly transferable to new branches of government, and the attraction of new challenges may explain his decision not to revert to a senior career in education.

In 1957, on the brink of retirement, Woofter published a reflection on the growing movement for civil rights and his own experiences as a campaigner for interracial cooperation and the eradication of lynching in the 1920s. It showed that, while his racial outlook had not altered significantly, he retained his optimism and faith in a strand of cautious southern white liberalism that linked men and women like Will Alexander, Lucy Randolph Mason, and Howard Odum - people committed to social justice, who reacted to the Great Depression with what southern journalist Ralph McGill called a "mighty surge of discussion, debate, self-examination, confession and release." ${ }^{, 73}$ Hundreds of trained social

\footnotetext{
72 Thomas Jesse Jones, ed., Negro Education: A Study of the Private and Higher Schools for Colored People in the United States, 2 vols. (Washington, D.C.: U.S. Government Printing Office, 1917).

${ }^{73}$ T. J. Woofter, Southern Race Progress: The Wavering Color Line (Washington, D.C.: Public Affairs Press, 1957); Ralph McGill, The South and the Southerner (Boston: Little, Brown, 1964), 159.
} 
scientists flocked to Washington, D.C., or state capitals to enter government service during the 1930s and 1940s, sensing a duty during a national emergency to equip politicians and planners with policy-oriented research. Woofter's career offers a clear example of an unusually durable and adaptable Progressive activist whose skills and evolving interests chimed with society's needs during the series of domestic and international crises that the United States faced between the birth of social security and the onset of the national security state.

For several decades after World War I, many public officials and academics in the United States were skeptical about the long-term benefits of close collaboration between policymakers and social scientists, but researchers like Jack Woofter, whose role ultimately, as Richard Nathan has put it, was that of "amplifying issues and elucidating options," could see the possibilities of policy-oriented scholarship and its contribution to the evolution of federal power. ${ }^{74}$ Woofter's shifting administrative status and the secrecy surrounding his final years in Washington may have contributed to an undeserved anonymity, but he was recognized by his fellow professionals for his skill and wisdom in co-ordinating major research programs and for his own work on race, farm economics, welfare, and demography. His clear and comprehensive reports - typified by Landlord and Tenant on the Cotton Plantation - his scholarship on the applications of research, and the methodological rigor of his projections concerning social programs and national security - were expressions of one of the most useful American social science careers in the middle years of the $20^{\text {th }}$ century.

\footnotetext{
${ }^{74}$ Richard P. Nathan, Social Science in Government: The Role of Policy Researchers (Albany, NY: Rockefeller Institute Press, 2000), 3, 5. On the shifting relationship between American social science and government, see Henry W. Riecken, "The Federal Government and Social Science Policy in the United States," in A. B. Cherns, R. Sinclair, and W. I. Jenkins, eds., Social Science and Government: Policies and Problems (London: Tavistock, 1972), 173-90.
} 